Mapping the Economic, Social and Technological Attributes of the SHARING ECONOMY

\title{
Abstract
}

Purpose: The sharing economy is a socio-economic system in which individuals acquire and distribute goods and services among each other for free or for compensation through Internet platforms. The sharing economy has attracted the interest of the academic community, which examined the phenomenon from the economic, social and technological perspectives.

Design: Given the lack of an overarching analysis of the sharing economy, this paper employs a quantitative content analysis approach to explore and synthesise relevant findings to facilitate the understanding of this emerging phenomenon.

Findings: The paper identified and grouped findings under four themes, namely: collaborative consumption practices, resources, drivers of user engagement and impacts, each of which is discussed in relation to the three main themes, aiming to compare findings and then put forward an agenda for further research.

Originality/value: The paper offers a balanced analysis of the building blocks of the sharing economy, to identify emerging themes within each stream, to discuss any contextual differences from a multi-stakeholder perspective and to propose directions for future studies.

Keywords: sharing economy, peer-to-peer economy, collaborative economy, collaborative consumption, quantitative analysis 


\section{Mapping the Economic, Social and Technological Attributes of the SHARING ECONOMY}

\section{Introduction}

A sharing economy is an umbrella concept denoting the practices of sharing, gift-giving and commodity-exchange (Belk, 2014). Facilitated by technological advances, the sharing economy has become an emergent socio-economic phenomenon performed through digital platforms (Kennedy, 2016). It has changed the way people access, consume and produce tangible and intangible resources within a new marketplace of collaborative and peer-to-peer online platforms (Botsman and Rogers, 2011).

The interest of the academic community in the disruptive powers of the sharing economy has increased exponentially over the past five years. The topic has evolved into a diverse body of knowledge that reflects the complexity of the sharing economy, covering the patterns of social interaction, economic transactions and technological attributes of this topical phenomenon. Such a rapidly developing field lends itself to being reviewed in a structured manner, in order to explore the emerging themes. There have been several overarching papers published on the sharing economy to date. However, they address limited research areas. Firstly, the papers focused on sharing practices in particular industries rather than the overall sharing economy. For example, a few papers examined key themes in tourism discourse (Dredge, 2015; Chen, 2016; Chan and Edwards, 2017), Becker-Leifhold and Iran (2018) explored consumer perspectives on the collaborative consumption of fashion industry products, Bouncken and Reuschl (2016) scrutinised the implications of coworking spaces in management practices, while Santos (2018) analysed a shared mobility concept. Secondly, studies recapped the speculations in the literature on the challenges that the sharing economy creates and the changes it brings to people's lifestyle (Duran-Sanchez 2016). For example, Morgan (2018) and Ganapati and Reddick (2018) discussed the impact of the sharing economy in general and the potential regulatory response in relation to some industries in particular. Thirdly, two publications limited the focus to only technological mediators of sharing practices. Knote and Blohm (2016) and Sutherland and Jarrahi (2018) recognised the importance of digital platforms and reviewed the attributes and characteristics that enable sharing economy practices. A more integrated approach was used by Trenz et al. (2018), who identified the types of sharing economy practices through a systematic approach and categorised them against underpinning dimensions. Although it contributes to the structuring of sharing economy practices, the paper does not tackle the economic, social and technological perspectives that are persistent in the research. Nor does it discuss the effect of the sharing economy on different domains of life.

Given the above, it is important to examine the sharing economy more holistically, comparing and analysing the relevant literature from an economic, a social and a technological perspective. The exploration of the economic and social facets of exchange can potentially bring a transformative agenda for further research on monetary and non-monetary practices (Hobson and Lynch, 2016). Considering the impact of sharing platforms on social and economic market relations, it is also important to examine the above from the perspective of the users and companies involved (Watanabe et al., 2017; Morgan and Kuch, 2015; 
Laamanen, Wahlen, and Campana, 2015; Herbert and Collin-Lachaud, 2016). Given the recent social trends towards a sustainable lifestyle and the capacity of the sharing economy to promote it (Hong and Vicdan, 2016), a multi-perspective approach will make it possible to grasp the profound meaning of the dimensions of this emerging phenomenon. As such, our paper's objective is to offer a balanced analysis of the building blocks of the sharing economy, to identify emerging themes within each stream, to discuss any contextual differences and to propose directions for future studies.

\section{Literature Review}

Collaborative practices performed in the sharing economy can be defined using Belk's (2014) conceptualisation of sharing, Botsman and Roger's (2011) definition of collaborative consumption and the definition of a peer-to-peer economy by Hamari et al. (2015). Although all three terms are used to explain the same phenomenon, they have different approaches to represent collaborative practices. Belk (2014) defines collaborative consumption as "people coordinating the acquisition and distribution of a resource for a fee or other compensation". The author differentiates collaborative consumption from gift-giving, sharing and commodity exchange by positioning it along the social - economic continuum (Figure 1). Ownership extension, ownership transfer and compensation are employed to delineate the boundaries of social and economic practices (Belk, 2010; Belk, 2014). However, the concept ownership can be confusing, because it refers to accessing a resource rather than permanent ownership. Ownership extension refers to access to a resource for collective use by its owner and temporary consumers, whereas ownership transfer refers to access to a resource for temporary use only by consumers. In some of the literature, the temporary use of a resource by the second party is referred to as an access-based consumption (Bardhi and Eckhardt, 2012). This term emphasises the lack of joint possession over the sharable object. The third concept is compensation. This denotes an economic or utilitarian reward for access to a resource. Unlike compensated practices, the resources can be shared on the basis of generalised reciprocity, which does not imply immediate obligation or expectation of return (Sahlins, 1974). Following Belk's conceptualisation, true sharing represents the practice under which a resource is collectively used by its possessor and consumers without compensation. During gift-giving the ownership is permanently transferred to another person for free. In contrast, commodity exchange enables temporary access to a resource for a fee (Belk, 2010; Belk, 2014). Collaborative consumption occupies a middle ground between the economic transactions of commodity exchange and a social act, like sharing and gift-giving. Unlike sharing, gift-giving and the commodity exchange dichotomy, the ownership and compensation one is not effective in classifying collaborative consumption. Rather, collaborative consumption captures various compensated and non-compensated practices representing temporary access to a resource for collective and individual use, temporary exchange of goods, and permanent transfer of second-hand resources (Belk, 2014; Bardhi and Eckhardt, 2012). 
Figure 1: Socio-economic continuum of sharing economy practices

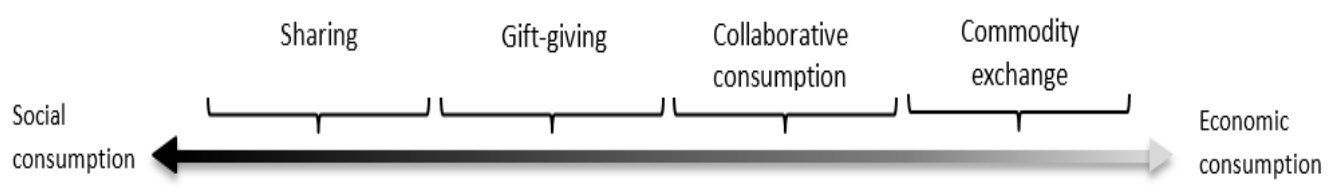

Botsman and Rogers (2011) define collaborative consumption as an "economic and cultural model based on systems of organised sharing, bartering, lending, trading, renting, gifting and swapping". The adoption of this approach puts compensated consumption, like bartering, trading, renting and lending, and non-compensated collaborative practices, like gift-giving and sharing, under one umbrella. Reflecting this definition against the conceptual boundaries proposed by Belk (Belk, 2010), collaborative consumption denotes practices that can be referred to as both gift-giving and commodity-exchange, thus misusing the concept. In contrast to Belk (2010) and Botsman and Rogers (2011), Hamari et al. (2015) defined collaborative consumption as a "peer-to-peer based activity of obtaining, giving, or sharing the access to goods and services, coordinated through community-based online services". It focuses on the activity taking place specifically within a digital peer-to-peer environment. The aforementioned definitions bring to light the fundamental characteristics of the sharing economy, which are: a) the nature of practices (social interaction or economic transaction), b) the type of reciprocation for access to a resource (generalised or compensated), c) the context, where practices are performed (market-based or communal environment) and d) the role of technology enabling the collaboration between parties. These characteristics contributed to the classification of the literature into economic, social and technological streams.

The fragmentation of perspectives may challenge research about consumer engagement when it comes to sharing economy benefits, user perceived drivers, barriers, attitudes and intentions. Also, unbalanced research potentially hampers the development of platforms for different user levels and markets, as well as undermining their implications for people's life and environment. However, no research has been undertaken to bridge the economic, social and technological perspectives, and shape the holistic picture of the sharing economy. The published research revolves around collaborative consumption practices, such as tourism, a shared mobility and a garment sector (Dredge, 2015; Chen, 2016; Chan and Edwards, 2017; Santos, 2018). In addition, scholarly works debate the impacts of the sharing economy. This is seen as the "Pandora's box" for sustainability, markets and institutions (Duran-Sanchez 2016; Morgan, 2018; Ganapati and Reddick, 2018). The speculations are rooted in the uncertainty of the nature of the phenomenon and what it may hold. The literature can benefit from a timely analysis directed towards the reconciliation of the research streams and a deeper understanding of all facets of the sharing economy. These will make it possible to inform future research and identify the advantages that the sharing economy holds. Therefore, we conducted a comprehensive multidimensional quantitative analysis of published research on the sharing economy. The following sections introduce the methodological approach adopted by the study and provide a discussion of the key concepts in each stream of the literature. 


\section{Methodology}

A preliminary scoping was undertaken to delineate the boundaries of the subject area, grasp the perspectives that had previously been tackled, explore the methodological approaches and discussions about the practical implications of the research. The iterative process made it possible to comprehend the heterogeneity of the conceptual underpinnings and disciplinary perspectives that had not been addressed in published review papers. After identifying gaps, the review protocol was developed. This aimed at guiding the phases of data analysis, paper selection, and interpretation.

A quantitative analysis method was adopted to analyse the identified sharing economy papers based on a keyword and its synonymous terms, such as "peer-to-peer economy" and "collaborative economy". The terms originated from widely-cited definitions that were used interchangeably to define the constellation of sharing and collaborative practices mediated by technology (Hamari, Sjöklint, and Ukkonen, 2015; Belk, 2014; Botsman and Rogers, 2011; Lessig, 2008). The quantitative approach to analysing published research makes it possible to inform theory through an exploratory yet impartial approach. To ensure the ecological validity of the findings, this study used theoretically guided methods of data sampling, analysis operationalisation and validation (Humphreys and Wang, 2017). As we wanted to cover the latest trends, we examined the period from 2013 to 2018. The search resulted in 446 papers, which, after the removal of duplicates across databases and when considering access rights, were reduced to 273 papers available for downloading. These were reviewed by the three reviewers to increase inter-rater reliability and those 149 papers selected by all three reviewers were included in the quantitative analysis. QDA Miner with its Wordstat extension was used for the analysis of papers, as it has been proved to provide robust results in research across diverse disciplines (Silver, 2014). The choice of the software is explained by its ability to integrate quantitative and qualitative features, process and manipulate alphanumeric data, provide varied text-analytical techniques with comprehensive graphic visualisation of results. The utilisation of Wordstat made it possible to interpret qualitative data through statistically significant concepts (represented by words) and themes (groups of concepts), thus increasing the replicability, objectivity and generalisability of the research design and findings (Riff, Lacy, and Fico, 2013). The quantitative content analysis was conducted in 6 steps: 1) the preparation of documents, 2) pre-processing, 3) feature extraction based on the analysis of the entire literature, 4) the classification of documents, 5) visualisation of the concepts discussed and 6) running the analysis of each stream. Preparation and pre-processing procedures were required to improve the accuracy of the results. The preparation step included the spell-check of the text, the removal of hyphens, square brackets and braces etc.. Pre-processing enabled lemmatisation, which featured automatic correction of misspellings and the substitution of concepts with word forms that had identical roots. In addition, the pre-processing required a manual check of the frequency list to exclude concepts not relevant to the study (Davi et al., 2005). In the third step, the content analysis was applied to 154 papers to select a subset of features reflecting all-embracing dimensions of the discourse about the sharing economy. Then the features were manually categorised, based on their relevance to social, economic or technological classes (Davi et al., 2005). The features were analysed within the textual environment from which they had been derived to validate the semantic relevance to the three classes. For the classification of documents an instance-based 
classification method was used that refers to supervised machine learning classification techniques, performed through manual categorisation of documents followed by computerassisted cross-validation of the classifiers (Kotsiantis, Zaharakis, and Pintelas, 2007). The manual categorisation of documents was conducted by cross-tabulating classified features against documents to produce the frequency list of classified features for each document. This process made it possible to assess the tendency of the document to fit a particular class and assign the class of dominant features to a document (Davi et al., 2005). The discriminative capability of the features was evaluated by a correlation test (Max Chi-square) that computed the highest co-occurrence value of the feature in one class against all other classes. As a result, manual classification of each feature was verified by an automatic class prediction and statistically confirmed by the $p$-value (Table 1). To cross-validate the accuracy of the classifier the $k$-Nearest Neighbour method was used, which worked on the principle that instances (classified features) of $k$ dataset existed in close proximity to the instances of other documents (Kotsiantis, Zaharakis, and Pintelas, 2007). Based on this, papers with an economic perspective comprised 75 papers, a social perspective 58 articles and a technological one 21 papers.

Table 1: Feature Selection for classification

\begin{tabular}{|c|c|c|c|}
\hline CLASS PREDICTION & NAME & Max $\mathrm{Chi}^{2}$ & $\mathbf{P}$ \\
\hline \multirow{12}{*}{ Economic } & PRICING & 33.35 & 0.00 \\
\hline & INSURANCE & 15.59 & 0.00 \\
\hline & TRANSACTION_COST & 10.96 & 0.00 \\
\hline & RETAIL & 10.36 & 0.00 \\
\hline & SHORTTERM_RENTAL & 9.81 & 0.00 \\
\hline & COMPETITOR & 9.29 & 0.00 \\
\hline & BUSINESS_MODEL & 8.41 & 0.00 \\
\hline & LIABILITY & 7.57 & 0.01 \\
\hline & REGULATION & 4.63 & 0.03 \\
\hline & ECONOMIC_BENEFIT & 4.62 & 0.03 \\
\hline & COST_SAVING & 4.00 & 0.05 \\
\hline & PURCHASE_INTENTION & 2.97 & 0.08 \\
\hline \multirow{13}{*}{ Social } & RECIPROCITY & 22.04 & 0.00 \\
\hline & COMMUNITY & 21.08 & 0.00 \\
\hline & NORM & 20.96 & 0.00 \\
\hline & SOCIAL_EXCHANGE & 13.06 & 0.00 \\
\hline & SUSTAINABILITY_CONSUMPTION & 9.05 & 0.00 \\
\hline & VOLUNTARY & 7.49 & 0.01 \\
\hline & SOCIAL_CONNECTION & 6.73 & 0.01 \\
\hline & COMMUNITY_BUILDING & 6.47 & 0.01 \\
\hline & SOCIAL_SPACE & 6.44 & 0.01 \\
\hline & SOCIAL_CAPITAL & 6.37 & 0.01 \\
\hline & GRASSROOTS_INNOVATION & 4.94 & 0.03 \\
\hline & SOCIAL_RELATION & 4.70 & 0.03 \\
\hline & UTOPIAN & 4.66 & 0.03 \\
\hline
\end{tabular}




\begin{tabular}{llll} 
& SOCIAL_RELATIONSHIP & 4.38 & 0.04 \\
& PSYCHOSOCIAL_WELLBEING & 3.97 & 0.05 \\
& DESIGN & 3.76 & 0.05 \\
& SOCIAL_PRACTICE & 3.30 & 0.07 \\
& GENERALIZE_EXCHANGE & 3.12 & 0.08 \\
\hline RATING_PREDICTION & 23.07 & 0.00 \\
& URBAN_MOBILITY & 23.07 & 0.00 \\
& ALGORITHM & 15.14 & 0.00 \\
Technology & 11.45 & 0.00 \\
& VIRTUAL_REPUTATION & 9.74 & 0.00 \\
& RECOMMENDATION_SYSTEM & 6.23 & 0.01 \\
& GIG & 4.52 & 0.03 \\
& INFRASTRUCTURE & 4.21 & 0.04 \\
& SMART & 2.77 & 0.10 \\
\hline
\end{tabular}

In the last steps of the quantitative content analysis concept mapping, frequency extraction, and proximity plotting were undertaken. Concept mapping and proximity plotting were performed through the co-occurrence analysis of two words, based on Jaccard's Index similarity coefficient defined as $J=a /(a+b+c)$, where $a$ is a paragraph of the document in which both words occur, and $a, b$ and $c$ represent the paragraphs where one of the words occur, but not the other (Tan, 2006). Concept map analysis was applied with the purpose of visualising the key themes discussed and defining the attributes (represented by concepts) of the sharing economy that underlined those themes. Then, the frequency analysis of each stream was run to manually group the derived attributes based on pre-defined categories. The deconstruction of the themes into attributes and the adoption of the pre-defined categories is justified by the goal of analysing the usage of the concepts in the three contexts and inferring the latent meaning (Hsieh and Shannon, 2005). The content analysis allowed us to describe, explain and compare differences between them. The analyses undertaken became a reference point for further qualitative interpretation and comparison of findings. The goal of the proximity plot was to visualise the relationship between the user and intermediary clusters and the derived categories of concepts. This illustrated the user perspective that the research took in discussing the topics.

\section{Results \& Findings}

\subsection{The Concept Map of the Sharing Economy}

Figure 2 presents concepts that underline the themes discussed about the sharing economy. The analysis grouped them into 5 categories. The category practices of consumption embraces the concepts defining joint activities related to resource acquisition and distribution among peers. The resources and implications category refers to a wide range of goods exchanged among users for compensation or for free within the context of alternative markets (e.g. transportation, accommodation, retail etc.). The category user engagement includes the variety of constructs and variables related to technology, market and personality that 
underline users' participation in the sharing economy. The impacts category covers the changes and challenges that the emergence of the sharing economy model has brought into the market, business, ecology and the consumer's life. Users are divided into supply-side and demand-side users. Supply-side users provide resources, such as hosts renting out flats in the $\mathrm{P} 2 \mathrm{P}$ accommodation market or car owners engaging in car sharing practices. Demand-side users acquire resources, such as apartment renters or buyers participating in retail transactions. Intermediates refer to platforms and companies that connect the two user groups, by representing the producers of services and goods to consumers. The next sections will present high-frequency concepts of the categories practices of consumption, resources and implications, user engagement and impacts, adopting economic, social and technological perspectives. The review will not present findings about the demand-side users, supply-side users and intermediaries concepts in a separate section, as they are discussed in relation to the concepts of other categories. 


\section{Figure 2: The sharing economy concept map}

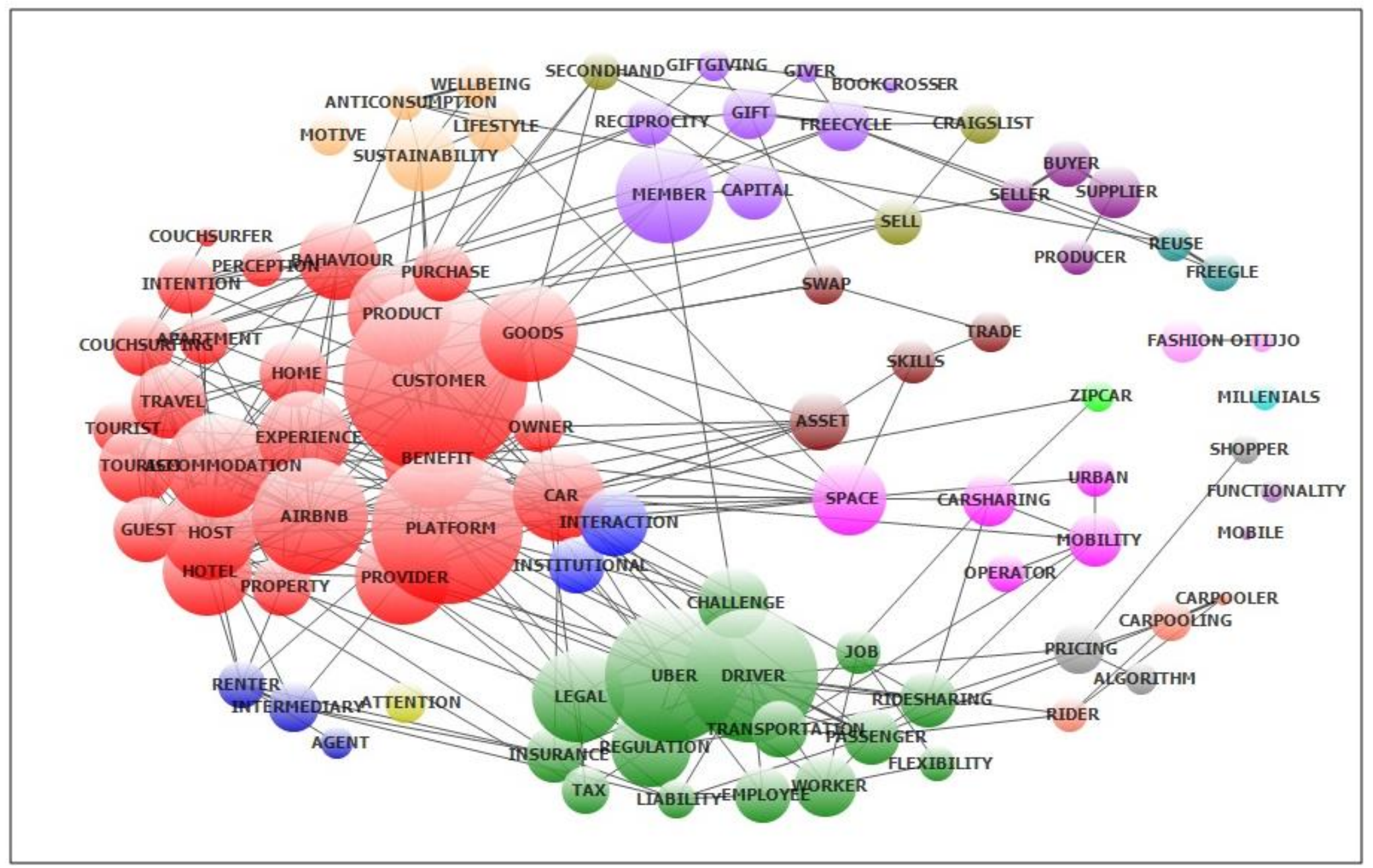




\subsection{Economic Perspective}

Table 2 presents the attributes of the sharing economy, represented by the frequency value, the percentage of processed terms calculated against the total number of words in the analysed documents and TF-IDF weight (the weighted term frequency adjusted against the inverse document frequency, containing this term). Published works revolved around the applications of the sharing economy in the transportation, accommodation, fashion and retail sectors. The economic and utilitarian dimensions of the sharing economy are credited to the technological premises that drive the phenomenon. The economic efficiency of technologymediated transactions represents the main stimulus of user engagement, which furthers the expansion of sharing platforms. Published work has also debated the impact of the phenomenon on people and the global market in general.

Table 2: The frequency of the main concepts underpinned by the economic perspective

\begin{tabular}{|c|c|c|c|}
\hline & $\begin{array}{c}\text { FRE } \\
\text { QUENCY }\end{array}$ & \% PROCESSED & TF • IDF \\
\hline \multicolumn{4}{|l|}{ STAKEHOLDERS } \\
\hline \multicolumn{4}{|c|}{ DEMAND-SIDE USER } \\
\hline CONSUMERS & 1298 & $0.23 \%$ & 0 \\
\hline CUSTOMER & 510 & $0.09 \%$ & 85.7 \\
\hline BUYER & 222 & $0.04 \%$ & 117.3 \\
\hline PASSENGER & 189 & $0.03 \%$ & 93.3 \\
\hline GUEST & 178 & $0.03 \%$ & 94 \\
\hline TOURIST & 117 & $0.02 \%$ & 64 \\
\hline RENTER & 109 & $0.02 \%$ & 66.2 \\
\hline MILLENNIALS & 77 & $0.01 \%$ & 93.1 \\
\hline SHOPPER & 77 & $0.01 \%$ & 93.1 \\
\hline \multicolumn{4}{|c|}{ SUPPLY-SIDE USER } \\
\hline PROVIDER & 701 & $0.13 \%$ & 123.4 \\
\hline SUPPLIER & 618 & $0.11 \%$ & 76.1 \\
\hline HOST & 402 & $0.07 \%$ & 146.5 \\
\hline EMPLOYEE & 311 & $0.06 \%$ & 109.5 \\
\hline OWNER & 129 & $0.02 \%$ & 36.8 \\
\hline SELLER & 52 & $0.01 \%$ & 34 \\
\hline \multicolumn{4}{|l|}{ INTERMEDIARY } \\
\hline PLATFORM & 2227 & $0.40 \%$ & 49 \\
\hline UBER & 1437 & $0.26 \%$ & 313.7 \\
\hline AIRBNB & 962 & $0.17 \%$ & 73.1 \\
\hline CRAIGSLIST & 156 & $0.03 \%$ & 188.7 \\
\hline OPERATOR & 137 & $0.02 \%$ & 65.4 \\
\hline ZIPCAR & 88 & $0.02 \%$ & 46.5 \\
\hline INTERMEDIARY & 53 & $0.01 \%$ & 37.3 \\
\hline \multicolumn{4}{|c|}{ PRACTICES OF CONSUMPTION } \\
\hline PURCHASE & 495 & $0.09 \%$ & 57.5 \\
\hline TRAVEL & 347 & $0.06 \%$ & 102.6 \\
\hline RIDESHARING & 273 & $0.05 \%$ & 121.8 \\
\hline CARSHARING & 261 & $0.05 \%$ & 142.7 \\
\hline SELL & 203 & $0.04 \%$ & 40.8 \\
\hline TRADE & 153 & $0.03 \%$ & 42.1 \\
\hline
\end{tabular}




\begin{tabular}{|c|c|c|c|}
\hline RESOURCES AND IMPLICATIONS & & & \\
\hline GOODS & 1634 & $0.29 \%$ & 35.9 \\
\hline CAR & 836 & $0.15 \%$ & 85.5 \\
\hline ASSET & 273 & $0.05 \%$ & 52.5 \\
\hline PROPERTY & 244 & $0.04 \%$ & 60 \\
\hline APARTMENT & 154 & $0.03 \%$ & 64.2 \\
\hline SECONDHAND PRODUCTS & 124 & $0.02 \%$ & 107.5 \\
\hline \multicolumn{4}{|l|}{ AREAS OF IMPLICATIONS } \\
\hline ACCOMMODATION & 1909 & $0.34 \%$ & 235.1 \\
\hline TRANSPORTATION & 1060 & $0.19 \%$ & 169.9 \\
\hline TOURISM & 360 & $0.06 \%$ & 190.2 \\
\hline FASHION & 187 & $0.03 \%$ & 117.8 \\
\hline \multicolumn{4}{|l|}{ USER ENGAGEMENT } \\
\hline PRICING & 1426 & $0.26 \%$ & 15.5 \\
\hline BEHAVIOR & 496 & $0.09 \%$ & 61.1 \\
\hline EXPERIENCE & 390 & $0.07 \%$ & 48 \\
\hline MOTIVE & 272 & $0.05 \%$ & 92.6 \\
\hline INTENTION & 230 & $0.04 \%$ & 125.8 \\
\hline SOCIAL_INTERACTION & 30 & $0.01 \%$ & 22 \\
\hline \multicolumn{4}{|l|}{ IMPACTS } \\
\hline REGULATION & 1120 & $0.20 \%$ & 197.2 \\
\hline SUSTAINABILITY & 896 & $0.16 \%$ & 150.6 \\
\hline LEGAL & 852 & $0.15 \%$ & 225.8 \\
\hline INSTITUTIONAL_CHANGE & 349 & $0.06 \%$ & 161 \\
\hline INSURANCE & 290 & $0.05 \%$ & 85.8 \\
\hline TAX & 206 & $0.04 \%$ & 75.1 \\
\hline
\end{tabular}

Figure 3 presents the proximity plot of the categories supply-side users, demand-side users and intermediaries with high-frequency concepts of retrieved clusters. The colours of the bars demonstrate the tendency to associate concepts with either consumers, suppliers or platforms. The plot demonstrated that the resources, trade and tourism concepts have been examined from all stakeholders' perspectives. The consumers' perspective underpins discussions about user engagement factors, travel and purchase practices within the accommodation sector. This reflects the tendency of the research to examine factors driving resource acquisition as opposed to their distribution. Given the economic conceptualisation of the sharing economy, past work has discussed its institutional and economic implications, mainly affecting intermediaries and suppliers in the transportation sector. 
Figure 3: Proximity plotting of the users and intermediaries categories with practices, resources, impacts and user engagement.

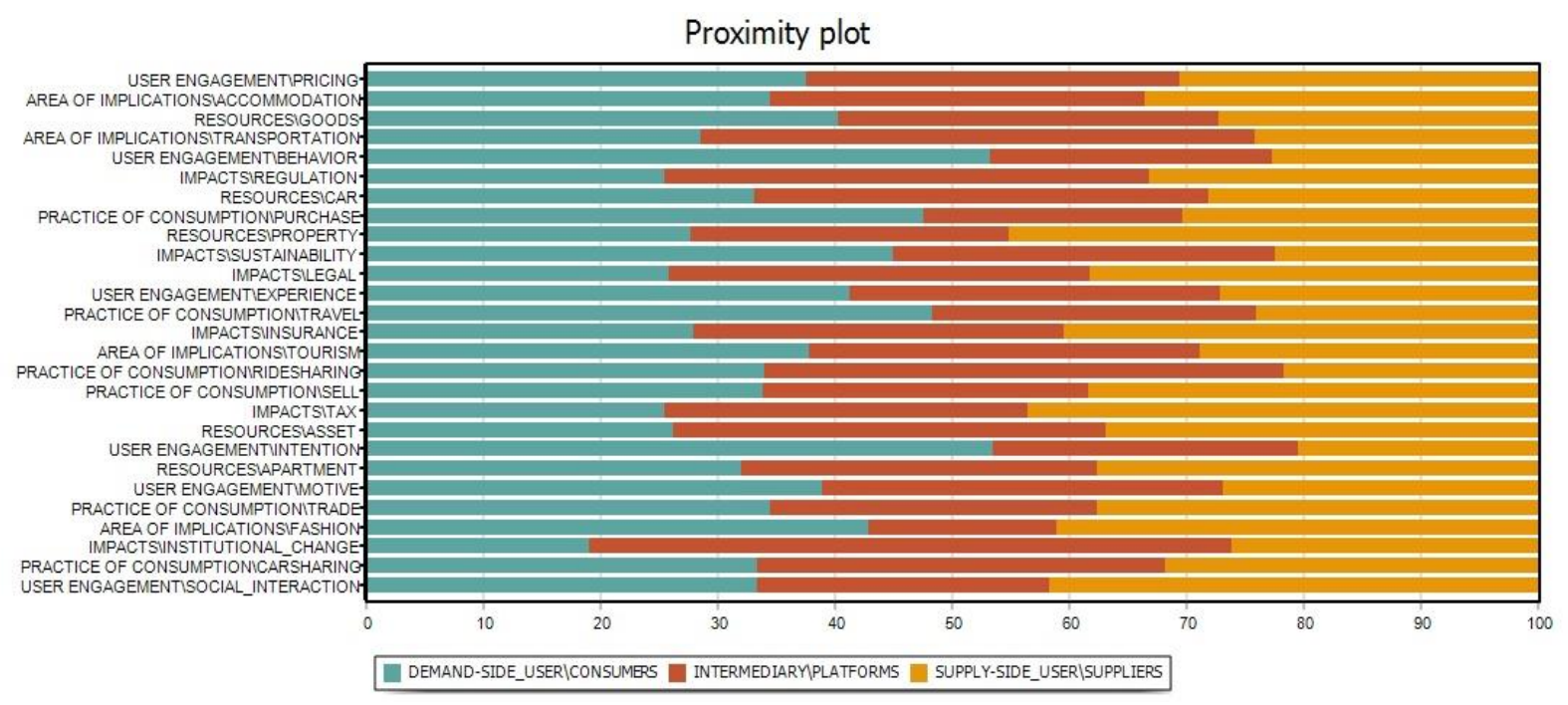

\subsubsection{Practices of consumption}

Collaborative Trading: There is a general predisposition to denote the utilitarian and financial value of the practices of trade, sell, purchase, ridesharing, carsharing and travel (Ballús-Armet et al., 2014; Posen, 2015; Retamal, 2017; Fremstad, 2017; Ertz, Durif, and Arcand, 2016; Hamari, 2013). Collaborative trading resembles market-based transactions, under which temporary access to a service, permanent transfer and exchange of resources are compensated (e.g. Ballús-Armet et al., 2014; Posen, 2015; Retamal, 2017; Fremstad, 2017). For example, trade practices appear to be channelled through unmediated (peer-to-peer) and mediated monetary exchanges. Trade is carried out through listings such as Craigslist, product-service systems (PSS), virtual accommodation marketplaces and online repositories of fashion items, referred to as fashion libraries (Fremstad, 2017; Esben Rahbek Gjerdrum and Sarah, 2015; Retamal, 2017; Karlsson, Kemperman, and Dolnicar, 2017; Hamari, 2013). Unmediated selling and purchasing through Craigslist represents the consumption, where terms and conditions are not moderated by the platform (Ertz, Durif, and Arcand, 2016; Fremstad, 2017). The practices result in profit maximisation made possible by the permanent transfer of the goods and services used from suppliers to consumers. Suppliers benefit from compensation for recirculating (selling and reselling) personal items in a consumption stream. Consumers' incentive to purchase second-hand items is encouraged by the reduced cost of an item (Ertz, Durif, and Arcand, 2016; Fremstad, 2017). Trading in product-service systems enables an individual to use services through access to platforms. This form of consumption takes the place of the purchase of a physical item by the rent of the service that the item produces (Retamal, 2017). Another form of trading is carried out through mediated peer-topeer accommodation platforms, such as AirBnb, and online fashion libraries (Karlsson, Kemperman, and Dolnicar, 2017; Belarmino et al., 2017; Oskam and Boswijk, 2016; Esben Rahbek Gjerdrum and Sarah, 2015). An emerging concept of fashion libraries and popular accommodation sharing platforms makes it possible to redistribute underused property and assets among consumers (Belarmino et al., 2017; Esben Rahbek Gjerdrum and Sarah, 2015). An intermediary actor controls the price of the temporary exchange of goods and becomes 
the third beneficiary of collaborative practices (Ertz, Durif, and Arcand, 2016). Intermediaries are responsible for marketing suppliers' offerings and matching them with consumers' needs. Considering profit incentives, companies implement recommendation systems, supplier reputation and ranking features to increase the reliability and safety of platforms (Karlsson, Kemperman, and Dolnicar, 2017; Fagerstrøm et al., 2017).

Collaborative Transport Practice: Recently, scholars have become increasingly interested in for-profit ridesharing, which is carried out through mediated and unmediated systems. During mediated ridesharing passengers acquire temporary use of a ride-service provided by the drivers of cars (Shaheen, Chan, and Gaynor, 2016; Watanabe et al., 2017; Sinclair, 2016; Ballús-Armet et al., 2014). The best-known example of mediated ridesharing is the Uber platform, which connects passengers and drivers through a mobile application (Watanabe et al., 2017; Sinclair, 2016). Ridesharing intermediaries have the power to manage orders, establish the rules of user relations, a pricing policy and the conditions of drivers' employment (Malin and Chandler, 2017; Posen, 2015). A few studies also explore peer-to-peer ridesharing, which represents a communal form of ride service consumption, whereby an owner shares a car during his/her trip to a destination with other passengers (Bálint and Trócsányi, 2016; Shaheen, Chan, and Gaynor, 2016). Users are empowered to build relations with each other, negotiate deal prices and change the distribution channels of their services and goods. The main difference of the latter from mediated ridesharing is the collective use of the ride service by the driver and the other passengers of the car (Bálint and Trócsányi, 2016; Ballús-Armet et al., 2014). The term carsharing has also been introduced to describe the practice whereby a supplier provides an automobile to a consumer in exchange for compensation. During carsharing passengers acquire the temporary use of a tangible resource, which is the car, opposed to the ride service it provides (Bálint and Trócsányi, 2016; Ballús-Armet et al., 2014). Despite the conceptual difference between the two transportation alternatives, in many instances, the terms ridesharing and carsharing are used interchangeably (e.g. Posen, 2015; Pfeffer-Gillett, 2016; Watanabe et al., 2017).

Collaborative Travelling: The sharing of transportation experiences and accommodation has been widely discussed in tourism research, which has explored the consumers' perspective on the consumption of alternative services in travel practices (Forno and Garibaldi, 2015; Karlsson, Kemperman, and Dolnicar, 2017; Bálint and Trócsányi, 2016; Tussyadiah and Pesonen, 2015). Transportation and accommodation sharing is explained by two conditions, namely the material efficiency of the product/service offering and the cognitive model of sharing (Ertz, Durif, and Arcand, 2016). On the material level, mediated collaboration represents a purely commercial venture. The cost of the exchange of cars made it possible to enjoy travel over short distances, which used to be an expensive service (Bálint and Trócsányi, 2016). Also, apartment sharing made it affordable for tourists to travel to foreign destinations (Tussyadiah and Pesonen, 2015). On the cognitive level, users follow the idea of the shared treatment of common objects. The cognitive state of mind exists when the technology does not mediate consumption (Ertz, Durif, and Arcand, 2016). This happens because technological mediation decreases the likelihood of individual subjective factors to foster social relationships among users and shape market-place transactions. 


\subsubsection{Resources and Implications}

Common Property: An emerging model of collaborative consumption of goods has introduced the notion of common property. This notion refers to an appropriated resource that is used collectively by commons. The juxtaposition of the words "common" and "property" is oxymoronic to a certain extent. This is so because the concept "common" defends communal interest, equality and collectivism in exchange, whereas the term 'property' stands for materiality and contractual obligations under which property is traded. The utilisation of the term puts a vague line between gifts and commodities, reflecting a non-dogmatic use of these terms (Morgan and Kuch, 2015; Frenken and Schor, 2017). Common properties and sharable assets relate to transportation, accommodation, tourism and the fashion industries (Sinclair, 2016; Esben Rahbek Gjerdrum and Sarah, 2015; Fremstad, 2017; Ballús-Armet et al., 2014; Kathan, Matzler, and Veider, 2016). Examined within the context of a market-based environment, resources bear economic and utilitarian value for users. The exploration of platforms on which resources are distributed results in their categorisation into five nonmutually exclusive groups, namely underutilised resources, on-demand resources, secondhand products, organisational goods and private resources (Fremstad, 2017; Gullstrand Edbring, Lehner, and Mont, 2016; Aloni, 2016).

Transport Resources: The system that is utilised to leverage an idle value of resources is defined as an access to excess platform (Aloni, 2016). This term specifies an access-based infrastructure through which resources are exchanged. Within transportation systems a common property is a car. Depending on the distribution system the transportation resource can be classified as an underutilised, on-demand, organisational and a private one. An underutilised resource refers to a good whose capacity has not been fully exploited by an owner. The exposure of the underutilised capacity of cars occurs when owners provide their idle assets for temporary possession by other consumers. The sharing of underutilised cars brings economic value to an owner in the form of compensation for the exchange. A consumer receives the utilitarian value of the resource operation and the financial value of reduced access (Ertz, Durif, and Arcand, 2016; Aloni, 2016; Birdsall, 2014). The distribution of on-demand resources offers immediacy of supply and the satisfaction of consumers' demand (Aloni, 2016). The most-widely discussed form of on-demand transportation resources are Uber cars. During ride-sharing, the passengers' demand for transport is fulfilled by access to the closest available car. On-demand supply of cars increases the efficiency of logistics, saves resources, reduces the item price and maintenance expenses (Laurell and Sandström, 2016; Malin and Chandler, 2017; Posen, 2015; Redfearn lii, 2016). Organisational resources are exchanged on a $\mathrm{B} 2 \mathrm{C}$ basis and refer to products belonging to companies. Car-sharing providers, such as ZipCar, City Carshare or Car2Go, offer company-owned cars through B2C channels (Posen, 2015; Cohen and Kietzmann, 2014). Conversely, private resources are distributed through direct exchange on peer-to-peer platforms (Aloni, 2016). Private cars are rented out by owners, who are responsible for the listing in the system and accountable for the services that the vehicles produce (Cohen and Kietzmann, 2014).

Accommodation Resources: An Apartment represents an underutilised resource distributed among consumers to satisfy demand for housing. Suppliers' provision of apartments is conditioned by the idleness of a resource and the possibility to match consumers' needs, 
budgets and taste (Wang and Nicolau, 2017). However, the value of private apartments that are shared through platforms such as AirBnb is not exclusively utilitarian and financial, due to the role of $\mathrm{C} 2 \mathrm{C}$ relationships that facilitate social interactions (Tussyadiah and Pesonen, 2015; Jiyoung and Merlyn, 2017; Belarmino, Whalen, Koh and Bowen, 2017). For example, in tourism, a consumer's decision to select an accommodation provider is based on both financial (price) and non-financial factors (the socio-demographic profile of suppliers and providers) (Heo, 2016; Karlsson, Kemperman, and Dolnicar, 2017). The compatibility of suppliers and consumers is an important factor in relationship development (Karlsson, Kemperman, and Dolnicar, 2017). This demonstrates that the stimuli of the resource exchange can define the value of a resource.

Retail Resources: Goods and second-hand products are exchanged through second-hand markets, product-service systems and on-demand platforms that can bear an underutilised meaning for the supplier and an on-demand value for the consumer. Typical products include fashion items, equipment, furniture and tools (Retamal, 2017; Esben Rahbek Gjerdrum and Sarah, 2015; Fremstad, 2017; Gullstrand Edbring, Lehner, and Mont, 2016). An alternative consumption stimulates the intensified use of goods of higher quality, higher monetary value and better durability (Retamal, 2017). Second-hand resources often relate to the sharing economy. Still, it is difficult to assign them to either the gift or commodity categories. This is because although individuals acquire permanent ownership of second-hand products as gifts the acquisition is based on monetary compensation (Belk, 2010; Frenken and Schor, 2017).

\subsubsection{User engagement}

Motives: Current research has found evidence of the influence of three main types of drivers on purchase intention and consumers' behaviour. The main one is an economic motive, followed by a social motive of relationship development and a hedonic motive of enjoying the practice. To a greater extent, consumers' decisions to engage in collaborative consumption are underpinned by users' interest in profit maximisation, the rationalisation of saving and investment (Hawlitschek, Teubner, and Gimpel, 2016; Tussyadiah and Pesonen, 2016; Gullstrand Edbring, Lehner, and Mont, 2016; Tussyadiah, 2015; Scaraboto, 2015; Hawlitschek et al., 2018). Economic benefits are enabled by ICT, whereby technological intermediation reduces the costs of goods and services by optimising the search, contract establishment and product allocation (Watanabe et al., 2017). The consumer's selection of a provider is underpinned by price-sensitivity, which controls the perception of the financial value and risk of participation in sharing practices (Jiyoung and Merlyn, 2017; Tussyadiah and Pesonen, 2015). Therefore, pricing strategies are imperative in regulating market demand and commercial relations between suppliers and consumers (Wang and Nicolau, 2017; Kung and Zhong, 2017). The examination of the sharing of private resources found that consumers are engaged in collaborative consumption for the sake of social interaction and shared experience (Tussyadiah and Pesonen, 2015; Lee and Kim, 2017; Belarmino, Whalen, Koh and Bowen, 2017; Tussyadiah and Pesonen, 2016). However, the significance of hedonic and social motives was not observed consistently throughout the studies reviewed.

Moderating Factors: The variability of findings about the significance of social and hedonic motives can be explained by two factors. Primarily, individual factors, such as user personality and socio-demographic status, may moderate the perception of benefits and barriers. 
Mediated access to services in the P2P accommodation market represents an economic transaction encouraging social practice that attracts consumers of different socio-economic status. Users of lower status and an older age are motivated by economic stimuli, whereas social and hedonic motives play the dominating role for wealthier and younger consumers (Tussyadiah and Pesonen, 2016; Hawlitschek et al., 2018). In addition, consumer innovativeness can influence the perception of the economic and hedonic values of collaborative practices (Jiyoung and Merlyn 2017; Tussyadiah and Pesonen, 2016). The second factor is the type of platform and collaborative practices (Gullstrand Edbring, Lehner, and Mont, 2016; Böcker and Meelen, 2017). For example, the survey of a sample of consumers engaged in the mediated consumption of goods found a distinctive group of barriers to engagement (Gullstrand Edbring, Lehner, and Mont, 2016). Users highlighted the sanitary conditions of goods, non-ownership, the impracticability of the alternative mode of consumption, the lack of trust and unavailability of resources as impeding factors of engagement (Gullstrand Edbring, Lehner, and Mont, 2016). In contrast, in accommodation sharing, which represents the practice of unmediated access to services, users prioritised hedonic and social motives (Tussyadiah and Pesonen, 2016; Böcker and Meelen, 2017). Moreover, the duration of involvement in collaborative consumption, measured by the time and frequency of peer-to-peer transactions, influence the perception of barriers. Consequently, individuals with a higher level of familiarity with platforms are more likely to express positive predisposition towards collaborative practices (Gullstrand Edbring, Lehner, and Mont, 2016; Lee and Kim, 2017; Tussyadiah and Pesonen, 2016). However, in the context of rental platforms, an intention to rent is contingent on the duration of rental services (Gullstrand Edbring, Lehner, and Mont, 2016). Even though the variability of results has not yet been fully explained, so far the evidence suggests that the most influential factors are the socio-demographic factors, the type of platform, resources and consumption practices on consumers' intentions.

\subsubsection{Impacts}

Environmental Impact: Reduced transaction costs and the overall efficiency of collaborative consumption can provide significant benefits for consumers, fuelling demand in alternative markets. The collaborative model of consumption makes it possible to reuse and recycle durable goods, idle resources, second-hand products and offerings exchanged through ondemand systems (Frenken and Schor, 2017; Esben Rahbek Gjerdrum and Sarah, 2015; Retamal, 2017; Fremstad, 2017; Boons and Bocken, 2018). The exploitation of these resources lowers the demand for new goods and services, resulting in less waste and the preservation of resources (Fremstad, 2017; Retamal, 2017). A longitudinal natural experiment based on the data on waste generation concluded that the expansion of the Craigslist platform in California and Florida (USA) reduced the solid waste in the states by one third (Fremstad, 2017). However, the effect of the sharing economy on resource preservation is more theoretical than actually observed (Bachnik, 2016; Rózycka, 2016). Any long-term impact of collaborative consumption on environmental sustainability has not been empirically shown (Frenken and Schor, 2017).

Institutional Impact: The potential of the ever-growing sharing economy is currently difficult to assess (Bonciu and Bâlgar, 2016; Retamal, 2017; Fremstad, 2017; Watanabe et al., 2017). A 
digital economy represents a double-edged sword. On the one hand, the non-accountability of companies to governments and the digital intermediation of platforms make it possible to keep the cost of services and goods down. This favours consumers and facilitates the expansion of platforms (Munkøe, 2017; Watanabe et al., 2017; Weber, 2014; Boons and Bocken, 2018). On the other hand, platform mediation of virtual markets leads to an institutional change, which refers to the change of rules governing market relations (Laurell and Sandström, 2016; Watanabe et al., 2017; Morgan and Kuch, 2015; de Leeuw and Gössling, 2016). From the suppliers' and intermediaries' perspectives, an institutional change brings immediate regulatory complexities and allegations because of the inability of suppliers to ensure the safety and privacy of users. Virtual marketplaces create conditions for companies to bypass obligatory legislation related to tax and insurance (Miller, 2016; Sprague, 2015). Moreover, the introduction of platforms has changed the fabric of the market and can affect the performance of incumbent firms. The floating pricing policy imposed by sharing platforms can lead to a collapse in prices on products and services of traditional suppliers, leading to a decrease in the overall profit margin of the market. In the long-term, the network effect may potentially threaten the global market by decreasing profitability and market homogeneity (Cusumano, 2015). Profits from digital transactions can fuel the grey economy, affecting the macro-economic capacity of countries (Watanabe et al., 2017; Dabrowska and Gutkowska, 2015). Given the disputes about the impact on incumbent firms and the global economy overall, long-term positive prospects are far from being certain. Paradoxically, both challenges and benefits are rooted in ICT, which has transformed business practice into a virtual marketplace (Watanabe et al., 2017; Dabrowska and Gutkowska, 2015).

\subsection{Social Perspective}

The literature has broadly discussed the social practices of consumption, which are not contingent on the reciprocal actions of users. These practices represent the exchange of tacit and tangible resources that bear social meaning for users. In this stream, consumption is driven by the motives of altruism, desire for social interaction and the attainment of authentic experience. The practices disrupt consumption habits, change lifestyle towards sustainability and lead to social wellbeing. Table 3 presents the high-frequency attributes of the sharing economy that reflect the findings and debates in the literature about the social dimensions of the practice of consumption, resources and their implications, user engagement factors and impacts.

Table 3: The frequency of the main concepts underpinned by the social perspective

\begin{tabular}{lccc}
\hline & FREQUENCY & \% PROCESSED & TF・IDF \\
\hline STAKEHOLDERS & & & \\
\hline DEMAND-SIDE USERS & & & \\
CONSUMERS & 1106 & $0.32 \%$ & 41.8 \\
MEMBER & 668 & $0.19 \%$ & 45.7 \\
CUSTOMER & 122 & $0.04 \%$ & 78.1 \\
GUEST & 74 & $0.02 \%$ & 44.6 \\
TOURIST & 61 & $0.02 \%$ & 51 \\
COUCHSURFERS & 49 & $0.01 \%$ & 48.1 \\
BOOKCROSSERS & 27 & $0.01 \%$ & 45.4 \\
SUPPLYSIDE USERS & & &
\end{tabular}




\begin{tabular}{|c|c|c|c|}
\hline PROVIDER & 215 & $0.06 \%$ & 81.7 \\
\hline HOST & 155 & $0.05 \%$ & 62.4 \\
\hline SUPPLIER & 129 & $0.04 \%$ & 28.2 \\
\hline DRIVER & 96 & $0.03 \%$ & 28.9 \\
\hline RENTER & 43 & $0.01 \%$ & 38.8 \\
\hline GIVER & 35 & $0.01 \%$ & 34.4 \\
\hline PRODUCER & 21 & $0.01 \%$ & 15.3 \\
\hline \multicolumn{4}{|l|}{ INTERMEDIARIES } \\
\hline PLATFORM & 504 & $0.15 \%$ & 34.5 \\
\hline FREECYCLE & 276 & $0.08 \%$ & 176.6 \\
\hline COUCHSURFING & 273 & $0.08 \%$ & 109.9 \\
\hline FREEGLE & 143 & $0.04 \%$ & 172.2 \\
\hline TIMEBANKING & 123 & $0.04 \%$ & 169.8 \\
\hline BOOKCROSSING & 83 & $0.02 \%$ & 139.5 \\
\hline UBER & 63 & $0.02 \%$ & 24 \\
\hline OITIJJO & 61 & $0.02 \%$ & 102.6 \\
\hline \multicolumn{4}{|c|}{ PRACTICES OF CONSUMPTION } \\
\hline PURCHASE & 243 & $0.07 \%$ & 60.7 \\
\hline SWAP & 157 & $0.05 \%$ & 53.2 \\
\hline TRADE & 129 & $0.04 \%$ & 34.3 \\
\hline REUSE & 92 & $0.03 \%$ & 49.2 \\
\hline GIFTGIVING & 83 & $0.02 \%$ & 81.5 \\
\hline CARPOOLING & 17 & $0.00 \%$ & 15.4 \\
\hline \multicolumn{4}{|l|}{ RESOURCES } \\
\hline PRODUCT & 811 & $0.24 \%$ & 7.4 \\
\hline SPACE & 357 & $0.10 \%$ & 40.4 \\
\hline HOME & 271 & $0.08 \%$ & 47.7 \\
\hline CAR & 253 & $0.07 \%$ & 41.2 \\
\hline GIFT & 200 & $0.06 \%$ & 60.2 \\
\hline SKILL & 146 & $0.04 \%$ & 32 \\
\hline \multicolumn{4}{|c|}{ AREAS OF IMPLICATION } \\
\hline ACCOMMODATION & 470 & $0.14 \%$ & 58.7 \\
\hline TOURISM & 216 & $0.06 \%$ & 168.1 \\
\hline \multicolumn{4}{|l|}{ USER ENGAGEMENT } \\
\hline EXPERIENCE & 402 & $0.12 \%$ & 23.3 \\
\hline BEHAVIOR & 400 & $0.12 \%$ & 54.9 \\
\hline CAPITAL & 396 & $0.12 \%$ & 31.4 \\
\hline MOTIVE & 283 & $0.08 \%$ & 42.4 \\
\hline INTERACTION & 248 & $0.07 \%$ & 22.4 \\
\hline RECIPROCITY & 210 & $0.06 \%$ & 49.2 \\
\hline \multicolumn{4}{|l|}{ IMPACTS } \\
\hline SUSTAINABILITY & 767 & $0.22 \%$ & 69.2 \\
\hline BENEFIT & 365 & $0.11 \%$ & 50.1 \\
\hline CHALLENGE & 288 & $0.08 \%$ & 8.1 \\
\hline LIFESTYLE & 249 & $0.07 \%$ & 94.7 \\
\hline WELLBEING & 158 & $0.05 \%$ & 101.1 \\
\hline ANTICONSUMPTION & 121 & $0.04 \%$ & 82.4 \\
\hline
\end{tabular}

Figure 4 demonstrates the proximity plot of the stakeholders concepts with the highfrequency concepts of other retrieved categories. The social perspective tends to examine the 
role of consumers, their experience and behaviour driving consumption practices. Consumers are deemed to play a pivotal role in social transformations towards anti-consumption, sustainable lifestyle and social wellbeing. The suppliers' perspective is adopted when it comes to exploring reciprocity, carpooling practice and the accommodation market. In contrast to the economic perspective, this stream focuses on the role of platforms in non-commercial forms of transactions, such as gift-giving and reusing, which foster social interaction between users.

Figure 4: Proximity plotting of the users and intermediaries categories with practices, resources, impacts and user engagement.

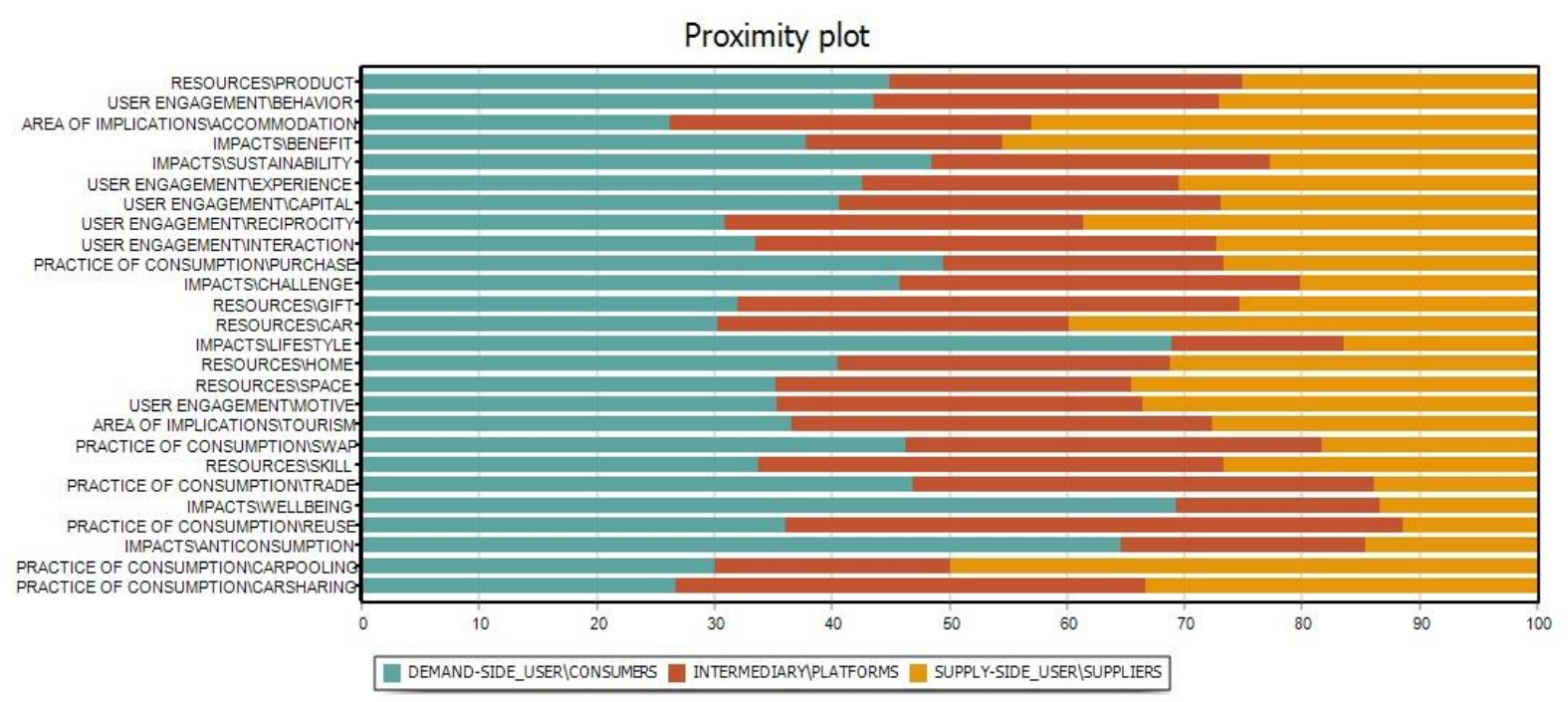

\subsubsection{Practices of consumption}

Defining Gift-Giving Practices: The distinctive type of practice that has emerged in this stream is gift-giving (Matteo and Daniele, 2014; Aptekar, 2016; Whitham and Clarke, 2016; Martin, Upham, and Budd, 2015; Yuan et al., 2018). A purely social depiction of this practice is rooted in the belief that it is based on generalised reciprocity. For example, the reuse of personal items through Freegle and Freecycle communities is interpreted as an altruistic and voluntary gift-giving practice, driven by environmentalism and the desire to minimise class inequality (Aptekar, 2016). However, the literature has also introduced a second interpretation of generalised reciprocity, whereby it assumes the return on exchange in future transactions (Aptekar, 2016; Matteo and Daniele, 2014; Whitham and Clarke, 2016). This perspective illustrates free reuse platforms as commercially-oriented markets of resource distribution (Whitham and Clarke, 2016; Martin, Upham, and Budd, 2015). The discrepant explanation of gift-giving practices is explained by different motives that actors manifest when engaging in the practice. The study by Matteo and Danielle (2014) illustrated different interpretations of social practices based on generalised reciprocity. The authors proposed that the transfer of resources from one member of the community to another could imply the notions of sharing, gift-giving and commodity exchange non-exclusively. The practices within a platform can be considered as sharing, because they enable members to collectively use resources through access. The consumption within a platform can also be considered as gift-giving, due to 
indirect reciprocity among the members of the community. Finally, gift-giving can be regarded as a commodity exchange, due to the latent commercial value that free access to resources implies for a receiver (Matteo and Daniele, 2014). This insight suggests that there is a fine line between gift-giving and sharing, as well as the social and economic values of consumption. The level of intimacy between parties varies depending on the role of the actors in the community, who can be either donating or receiving. However, the assumption that gift-giving and sharing facilitate utilitarian values would be misleading, unless the motives of users are known.

Social Roots of Collaborative Consumption: The literature discusses collaborative consumption practices like swapping, carpooling, trading and purchasing as a reflection of social exchange (Hong and Vicdan, 2016; Shaheen, Chan, and Gaynor, 2016; Lamberton, 2016; Begum and Anjum, 2016; McArthur, 2015; Yuan et al., 2018). For example, home swapping in Couchsurfing communities represents free exchange or sharing, characterised by a high degree of service personalisation (Forno and Garibaldi, 2015). In contrast, carpooling is a casual form of reciprocal sharing of a ride with another passenger, whereby the service is financially compensated to a driver. The social aspect of carpooling practices has led to examining the users' role in consumption practices (Shaheen, Chan, and Gaynor, 2016; Yang et al., 2017; Ellen, 2015; Herbert and Collin-Lachaud, 2016). Specifically, it was found that vehicle drivers engaging in carpooling share common socio-demographic patterns, such as age and employment status (Shaheen, Chan, and Gaynor, 2016). Trading and purchasing are conducted on time-banking, marketplace and food exchange sites. Although the practices imply explicit reciprocation, consumers are stimulated by the values of environmentalism, developing peer relationships and building an egalitarian community (Piscicelli, Cooper, and Fisher, 2015; Shaheen and Chan, 2016; Huber, 2017; Yang et al., 2017; Voytenko Palgan, Zvolska, and Mont, 2017; Schor et al., 2016). These practices do not result in a robust demand-supply match, which undermines the traditional notion of the trading economy (Schor et al., 2016). Hence, the idea that the compensated exchange has an economic value would be based on a superficial assessment of the practices. The concept of the sharing economy is mainly translated through the understanding and vision of consumers, whereas their motives become a proxy for defining the social or economic nature of consumption (Gruszka, 2017; Geigerrr, Horbel and Germelmann, 2017). The supporters of social framing associate the sharing economy with non-profit initiatives that stand for fair, connected and sustainable communities. The proponents of economic framing support collaborative practices for the sake of creating new employment and market opportunities (Gruszka, 2017).

\subsubsection{Resources and implications}

Gifts or Debts: The products and services circulating in the sharing economy are often symbolically called gifts (Aptekar, 2016; Matteo and Daniele, 2014; Geigerr, Horbel and Germelmann, 2017). The conditions upon which gifts are exchanged in the sharing economy are debatable. On the one hand, a gift has no cost for a receiver, although it causes emotional dependence and subordination to a giver (Geigerr, Horbel and Germelmann, 2017). The feeling of gratitude for the gesture of good will is akin to the feeling of indebtedness. It puts a receiver into an inferior position, making it possible for the donor to control and manipulate the beneficiary of the gift (Aptekar, 2016; Waite and Lewis, 2017). This makes the resource a 
covert lever in peer-to-peer relations. For example, guests can engage in domestic labour that they carry out for the exchange of goods and shelter. The relations are based on moral commitment to acknowledge hosts' kindness (Waite and Lewis, 2017). Some rituals resemble a charity act, though, which requires unwilling gift-giving for the sake of social approval and reputation (Matteo and Daniele, 2014).

Intangible Resources: Skills can be an intangible form of gift or sharable knowledge. The sharing or exchange of skills is driven by partners' non-reciprocal commitment to spreading the knowledge among like-minded people (Begum and Anjum, 2016; Barnes and Mattsson, 2016). However, the role of motives, such as altruism, social approval, reciprocation of a reward amongst others, has not yet been studied in depth. Although skills facilitate the development of relations in social exchange, this raises the question as to which type of practice (sharing or gift-giving) is being referred to. Due to the intangibility of skills, it is difficult to assess whether the ownership is temporary or permanent. It is also unclear whether the resource is used by the giver and receiver simultaneously or transferred for individual use by a receiver. Another intangible resource is space, which serves as a shared working venue for collaborative communities. Space creates a high degree of intimacy and solidarity among actors (Begum and Anjum, 2016; Bouncken and Reuschl, 2016; Barness and Mattsson, 2016). The resource is social by nature, triggering interaction development and producing social relations as a granted outcome.

Tangible Resources: Products that represent tangible resources have been considered mostly in the context of free transactions in online communities (Geigerr, Horbel and Germelmann, 2017; McArthur, 2015; Hong and Vicdan, 2016; Huber, 2017; Voytenko Palgan, Zvolska, and Mont, 2017). Free sharing encourages the increase of users' demand for used products and reduces the consumption volume of new ones (Binninger, Ourahmoune, and Robert, 2015; Barness and Mattsson, 2016). Sharing of homes and cars helps users to fulfil their social needs (Hong and Vicdan, 2016). Unlike AirBnb apartments, the exchange of homes is performed under the condition of resource availability rather than monetary compensation. While the economic value of the resource is arguably a motivational factor, the practices are framed as social movements (Forno and Garibaldi, 2015; van Nuenen, 2016; Voytenko Palgan, Zvolska, and Mont, 2017). The home represents the venue reconciling hosts and guests, putting guests into the local cultural context, thus turning a stranger into an insider in the community (van Nuenen, 2016). The development of relations between a home supplier and a guest facilitates social inclusion (Cockayne, 2016). The hedonic value of a resource is reflected by the authenticity of the home sharing experience (Richardson, 2015; van Nuenen, 2016; Dickinson et al., 2017; Wyatt, 2014; Schor et al., 2016). At the same time, research determines utilitarian value, whereby the accommodation and transportation resources represent an alternative and cost-effective way to accomplish mobility and housing needs (Shaheen, Chan, and Gaynor, 2016; Gruszka, 2017). The identification of the values of material resources is more complicated. Cars, homes and other products have explicit utilitarian value, while social property is implicit and inconsistent. The exploitation of their social value is dependent on the degree of reciprocation that collaborative practice implies. The lack of obligation and the expectation of reciprocity suggest that the practice is based on social principles. 


\subsubsection{User Engagement}

Social Capital: User engagement has been examined primarily through the social capital perspective (Barness and Mattsson, 2016; Kim, Lee, Koo and Yang, 2017; Ferrari, 2017; Dickinson et al., 2017; Schor et al., 2016; Yuan et al., 2018). Social capital is a pervasive concept that embraces resources produced through the networks of human relations (Ferrari, 2017; Kim, Lee, Koo and Yang, 2017). Social capital is expressed through four dimensions: motivational (e.g. the enjoyment of sharing), structural (e.g. the number of social ties in the network), cognitive (e.g. shared experience) and relational (e.g. reciprocity) (Nahapiet and Ghoshal, 1998; Kim, Lee, Koo and Yang, 2017). These dimensions construct the analytical framework for examining the factors in sharing intention and the user engagement process (Kim, Lee, Koo and Yang, 2017). So far, the research has found a direct influence of three types of factors: motivational, cognitive and relational (Kim, Lee, Koo and Yang, 2017; Harvey, Smith, and Golightly, 2014; Whitham and Clarke, 2016; Geigerr, Horbel and Germelmann, 2017). These forms of social capital reflect user values, shared experience about the participation in the network and the conditions under which the interaction between users occur. The role of the aforementioned forms of social capital is moderated by trust (Kim, Lee, Koo and Yang, 2017). The structural aspect refers to the external dimension, which reflects the number and the centrality of the user's connections within the network (Ferrari, 2017; Kim, Lee, Koo and Yang, 2017). This has not been examined thoroughly, but it could point to user expectations of the network against current positioning within it.

Motivational and Cognitive Dimensions: To a greater extent, consumers' decisions to join a community are conditioned by intrinsic motivation, reflecting the enjoyment from sharing. This motive has been examined in relation to the practices of home-swapping, land-sharing and space-sharing (Voytenko Palgan, Zvolska, and Mont, 2017; Lampinen, Huotari, and Cheshire, 2015; Huber, 2017; McArthur, 2015; Forno and Garibaldi, 2015). The enjoyment of collaboration may bring greater satisfaction than the material outcome of practice (McArthur, 2015). The manifestation of enjoyment is contingent on cognitive constructs, such as shared knowledge and experience. However, intention to share and behaviour are dependent on expectations and the perception of values derived from prior experience and interaction. The more experience and time as part of the community users have, the less likely they have the intention to stay as members of this community. This finding suggests that the time spent in the community moderates intention (Kim, Lee, Koo and Yang, 2017). Moreover, consumers' engagement in social practice cannot be entirely credited to intrinsic factors. Sustainability is a second motive driving user decisions and behaviour. The sustainability value reflects the user mind-set pursuing the reduction of new resource consumption or the replacement of new products with used ones (McArthur, 2015; Kim, Yoon, and Zo, 2015; Hong and Vicdan, 2016; Aptekar, 2016). The sustainability factor is significant in the reuse and recycle practices carried out on the Freecycle platform (Aptekar, 2016).

Relational Dimension: The motive of seeking social interaction is manifested when users intend to support the sense of community and develop social ties. The relationships among users are built through repeated collaboration with members they trust (Lampinen, Huotari, and Cheshire 2015). The generalised reciprocity concept is central to understanding the behavioural patterns of users and regulating relations between members of the community 
(Lampinen, Huotari, and Cheshire, 2015; Geigerr, Horbel and Germelmann, 2017; Ferrari, 2017; Piscicelli, Cooper, and Fisher, 2015; Huber, 2017; Whitham and Clarke, 2016; Barness and Mattsson, 2016; Kim, Lee, Koo and Yang, 2017). In the context of social exchange, generalised reciprocity has a disputable impact on suppliers' decisions to share. There are two streams of thought that reflect the understanding of the degree of obligation that generalised reciprocity entails (Geigerr, Horbel and Germelmann, 2017; Belk, 2010; Matteo and Daniele, 2014; Kim, Lee, Koo and Yang, 2017). The first perspective regards it as a non-binding form of transaction, which implies a greater contribution from providers than consumers. The practices resemble true sharing, which represents a burden for the supplier, unless it occurs between close people. Therefore, suppliers have less interest in the social exchange compared to the economic one (Geigerr, Horbel and Germelmann, 2017; Belk, 2010). The other perspective stems from the idea that non-binding and non-compensated forms of consumption rarely hold true (Kim, Lee, Koo and Yang, 2017; Matteo and Daniele, 2014). Generalised reciprocity often entails unintentional compensation based on an emotional obligation. Compensation can come from the receiver or other members of a community (Matteo and Daniele, 2014). Thus, the obligation to reciprocate is among the key drivers of social exchange, which maintains the viability of the sharing mode of consumption (Kim, Lee, Koo and Yang, 2017; Matteo and Daniele, 2014). The misconception of generalised reciprocity makes it difficult to evaluate the degree to which non-compensated practice has a utilitarian or social value.

\subsubsection{Impacts}

Social Wellbeing: The societal benefit of sharing is community wellbeing. This is achieved through the development of social ties and social inclusion (Barness and Mattsson, 2016; Kim, Lee, Koo and Yang, 2017). These impacts refer to the relational group of benefits. Relational benefits lead to the reinforcement of trust, solidarity and users' self-confidence resulting from social interactions, as well as commitment in relation to other members of a community (Yang et al., 2017; Ferrari, 2017; Begum and Anjum, 2016). Still, a few scholars were concerned that social capital may influence the exclusion of a person from the community (Ferrari, 2017; Schor et al., 2016). This could potentially happen when the network imposes restrictions on the quantity or the profile of members. The reputation history of a user may also affect the likelihood of future transactions (Schor et al., 2016). Despite the speculations, the exclusive effect of engaging in a sharing economy has not been empirically examined. Relational benefits remain the subject of debate.

The Path Towards Sustainability: The sharing economy can have a transformative effect on consumer choices, and cultural and economic practices (Herbert and Collin-Lachaud, 2016; Laamanen, Wahlen, and Campana, 2015; Hendry et al., 2017). The phenomenon has a structural impact that disrupts the foundations of consumption, including beliefs, values and norms towards the reduction of consumption (anti-consumption) (Laamanen, Wahlen, and Campana, 2015). The socio-technical approach distinguishes the positive role of digital intermediation and social interaction in facilitating anti-consumption movements. Digital attributes enhance resource utilisation, whereas social interactions during the process of collaborative consumption facilitate the balance of resource distribution among members (Martin, Upham, and Budd, 2015). The change of consumer behaviour towards a sustainable 
lifestyle will contribute to environmental sustainability, which is deemed to be a tool stabilising inequalities in diverse market economies (Hobson and Lynch, 2016; Hong, Shin, and Lee, 2016; Martin, Upham, and Budd, 2015; Hendry et al., 2017). Despite the growing number of academic studies and governmental interventions to alter the culture and consumer behaviour, the sharing economy's contribution to sustainability promotion remains at a conceptual stage.

\subsection{Technological Perspective}

Table 4 presents the frequency of the main concepts related to the technological aspects enabling collaborative consumption. The main focus is on ridesharing practices and the exchange of space, apartments, products, homes and property. The research studies consumption practices as a function of platforms that manage the behaviour and interaction of users. Scholars also consider technology when it comes to exploring the impacts on mobility, sustainability, flexibility and labour management challenges that the sharing economy entails.

Table 4: The frequency of the main concepts underpinned by the technological perspective

\begin{tabular}{|c|c|c|c|}
\hline & FREQUENCY & \% PROCESSED & $\overline{T F} \bullet$ IDF \\
\hline \multicolumn{4}{|c|}{ USERS AND INTERMEDIARIES } \\
\hline \multicolumn{4}{|l|}{ CONSUMER } \\
\hline CONSUMER & 279 & $0.44 \%$ & 22.1 \\
\hline WORKER & 69 & $0.11 \%$ & 26.2 \\
\hline PASSENGER & 52 & $0.08 \%$ & 24.8 \\
\hline CUSTOMER & 18 & $0.03 \%$ & 3.2 \\
\hline \multicolumn{4}{|l|}{ SUPPLIER } \\
\hline DRIVER & 362 & $0.57 \%$ & 109 \\
\hline CONTRACTOR & 26 & $0.04 \%$ & 12.4 \\
\hline SUPPLIER & 26 & $0.04 \%$ & 9.9 \\
\hline PROVIDER & 19 & $0.03 \%$ & 7.2 \\
\hline EMPLOYER & 14 & $0.02 \%$ & 10.9 \\
\hline \multicolumn{4}{|l|}{ INTERMEDIARY } \\
\hline PLATFORM & 284 & $0.45 \%$ & 35.5 \\
\hline UBER & 282 & $0.45 \%$ & 66 \\
\hline SYSTEM & 201 & $0.32 \%$ & 0 \\
\hline AIRBNB & 46 & $0.07 \%$ & 10.8 \\
\hline AGENT & 35 & $0.06 \%$ & 16.7 \\
\hline \multicolumn{4}{|c|}{ CONSUMPTION PRACTICE } \\
\hline RIDESHARING & 51 & $0.08 \%$ & 24.3 \\
\hline \multicolumn{4}{|c|}{ RESOURCES AND IMPLICATIONS } \\
\hline CAR & 108 & $0.17 \%$ & 25.3 \\
\hline PRODUCT & 92 & $0.15 \%$ & 3.5 \\
\hline APARTMENT & 63 & $0.10 \%$ & 37.9 \\
\hline SPACE & 28 & $0.04 \%$ & 3.5 \\
\hline HOME & 27 & $0.04 \%$ & 2.1 \\
\hline CAR & 108 & $0.17 \%$ & 25.3 \\
\hline \multicolumn{4}{|c|}{ AREA OF IMPLICATION } \\
\hline TRANSPORTATION & 116 & $0.18 \%$ & 44.1 \\
\hline USER ENGAGEMEN1 & & & \\
\hline
\end{tabular}




\begin{tabular}{|c|c|c|c|}
\hline EXPERIENCE & 111 & $0.18 \%$ & 4.2 \\
\hline ALGORITHM & 98 & $0.16 \%$ & 29.5 \\
\hline BEHAVIOR & 71 & $0.11 \%$ & 2.7 \\
\hline PRICING & 61 & $0.10 \%$ & 7.6 \\
\hline INTERACTION & 49 & $0.08 \%$ & 6.1 \\
\hline FUNCTIONALITY & 25 & $0.04 \%$ & 19.5 \\
\hline \multicolumn{4}{|l|}{ IMPACTS } \\
\hline MOBILITY & 88 & $0.14 \%$ & 53 \\
\hline JOB & 58 & $0.09 \%$ & 17.5 \\
\hline URBAN & 44 & $0.07 \%$ & 16.7 \\
\hline SUSTAINABILITY & 36 & $0.06 \%$ & 21.7 \\
\hline CHALLENGE & 29 & $0.05 \%$ & 3.6 \\
\hline FLEXIBILITY & 23 & $0.04 \%$ & 8.7 \\
\hline
\end{tabular}

Figure 5 demonstrates that past work adopted predominantly intermediaries' perspectives in exploring practices in the transportation sector, user engagement factors (such as interaction and platform functionality) and the impacts on urban infrastructure, mobility and sustainability. The consumers' perspective prevails in discussions about the role of platform algorithms in regulating consumer behaviour, especially when it comes to the exchange of products and homes. The suppliers' perspective dominates the discussions about the role of technology in managing product pricing and experience with platform vendors. The proximity plot also shows the focus on suppliers in examining service flexibility and labour management.

Figure 5: Proximity plotting of the users and intermediaries categories with practices, resources, impacts and user engagement.

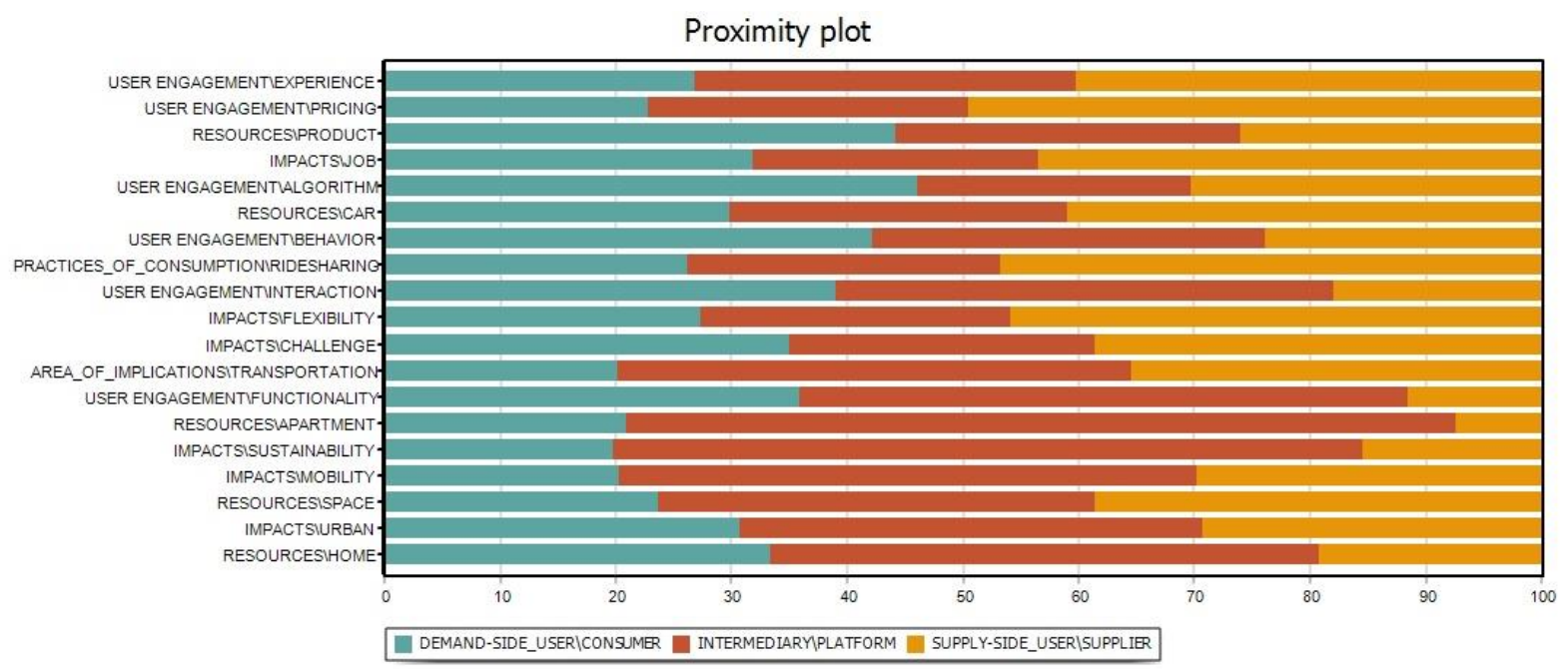

\subsubsection{Practices of consumption}

Technological Framing of Collaborative Consumption: The sharing economy is framed as the outcome of technology advancement (Rosenblat and Stark, 2016; Gargiulo et al., 2015; Yeonsun and Chang-Hee, 2016; Ambrosino et al., 2016; de Rivera et al., 2017). It is described as a distributed intelligence network that matches supply and demand. This phenomenon could potentially grow into a global economic system functioning without the intermediation of 
money. The technological framing diminishes the social and economic foundations of collaborative consumption, highlighting the shortcomings of the social and monetary aspects of exchange. The limitation of monetary exchanges is that money does not represent a holistic measure to assess the value of sharing. Money is a one-dimensional construct unable to reflect different aspects of the value of a product/service, such as reliability, aesthetics and sustainability. The importance of a social factor in managing relations on platforms is also not emphasised. Social capital, such as trust, is ineffective in regulating relations in large-scale networks (Gargiulo et al., 2015).

Ridesharing: Due to the lack of emphasis on the social and economic dimensions of the sharing economy, scholars do not differentiate practices into sharing, gift-giving or commodity exchange. Consequently, ridesharing is defined as a real-time matching of supply and demand, regulated by intelligent systems of algorithms (Rosenblat and Stark, 2016; Gargiulo et al., 2015). Technically, ridesharing represents a decentralised system of applications, enabled by artificial intelligence (AI) and embedded into the devices of users (Heylighen, 2017). The system has been materialised by Uber. The role of drivers in this supply-chain system is debatable and dependent on the state laws where the platform has been implemented. Drivers may be referred to as independent contractors, but they are still constrained by employer rules. Earning money is the main reason that motivates Uber employees, who are often deprived of high-profile employment opportunities (Rosenblat and Stark, 2016). The social aspect of relations between a driver and a passenger is downplayed due to the algorithm that matches inquiries against time and space, and proposes the route to optimise drivers' and passengers' journeys (Gargiulo et al., 2015). Uber demonstrates that purely technological regulation of platforms is not viable. Even if digital intermediation minimises the role of money in the relations between the driver and passenger, the drivers' decisions to perform their duties are triggered by monetary reward.

\subsubsection{Resources and Implications}

System Classification: The characteristics of exchanged products and property differ depending on the type of technology system (Heylighen, 2017; de Rivera et al., 2017). Technology systems can be classified based on 4 parameters that define the value and characteristics of the resources. These parameters are usability and functionality, trust and reputation, the community footprint and rules of conduct (de Rivera et al., 2017). Usability and functionality refers to the functions that are responsible for building user profiles, creating user identities, ensuring interconnectivity, integrating add-on services and interactive design. Trust and reputation systems enable vendor ranking and ensure the transparency of usage patterns. The availability of rules of conduct is aimed at controlling users' behaviour on a platform. The community footprint refers to the geographical coverage, and the capability of a system to carry out social and environmental missions. The particular combination of the four dimensions classifies the platform into three types: 1) network-oriented platforms, which embrace the combination of the trust and reputation and the functionality and usability features; 2) community-oriented platforms, which include all dimensions with the highest performativity of the community footprint and the rules of conduct features; 3) transactionoriented platforms, which lack any of the dimensions, and are characterised by simple functions (de Rivera et al., 2017). 
Resource Classification: Depending on the platform classification, cars represent resources that meet community and utilitarian needs. The sharing of cars is arranged through the system of connected mobile applications, whose aim is to provide passengers with dynamic car-riding services (Gargiulo et al., 2015). The system ensures the quality of service managed through instant feedback features and algorithms. The ability to provide ubiquitous and mobile interconnectedness and improve the mobility of community members gives the resource a communal orientation. Cars also represent the resource exchanged in transactionoriented systems (Ambrosino et al., 2016; Furman, 2016). Such a system does not integrate sophisticated features of trust regulation, thus endowing the resource with a merely utilitarian value. Similarly, apartments and homes are examined within the context of a transaction-oriented system that demonstrates their economic value (Yeon-sun and ChangHee, 2016; Zhang et al., 2018). Consequently, the value of the same resource can differ depending on the explicit characteristics of the system within which it is shared.

\subsubsection{User engagement}

Econo-Technological Features: The major factor driving consumer choices and behaviour is the functionality of platforms. The level of functionality refers to the degree of the embeddedness of features enabling user connectivity around platform offerings (Kim and Yoon, 2016; Heylighen, 2017; Lombardi and Schwabe, 2017). Similar to the economic perspective, studies highlight price as a major contributor to consumers' decision making (Kim and Yoon, 2016; Heylighen, 2017; Rosenblat and Stark, 2016; Lombardi and Schwabe, 2017). However, unlike the economic perspective, past work minimises the human role in rationalising price-led choices and product preferences. System algorithms between providers and consumers do the matching, assessment and selection of providers' offerings instead of consumers (Heylighen, 2017). The price-based selection of a vendor is managed by a pricematching algorithm embedded into the recommendation systems of the platforms. Algorithms help generate the coherent output of potential matches that meet consumers' price criteria (Heylighen, 2017; Lombardi and Schwabe, 2017). In practice, peer-to-peer accommodation platforms offer the best matches, by estimating users' interests and needs through the history of their behaviour on platforms (Kim and Yoon, 2016).

Socio-Technological Features: The functionality of community-oriented platforms fosters the social aspects of exchange. Reputation is one of the pillars of sharing platforms that maintains interactions between users. It enables the development of social capital, such as trust and virtual reputation (Gretzel et al., 2015; de Rivera et al., 2017; Heylighen, 2017; Zhang et al., 2018). In collaborative communities social capital is accumulated through personal relations between peers (Ferrari, 2017). In technically sophisticated sharing networks a prior experience with the vendors is not required to build trustworthiness. A system generates the profile of suppliers by scoring their reliability based on rankings and the experience of previous consumers (Heylighen, 2017). Algorithms also track and evaluate suppliers' actions against ethical and safety principles (de Rivera et al., 2017). These features increase the transparency of relations, help monitor the quality of the service and drive consumers' engagement (Heylighen, 2017; de Rivera et al., 2017). Technological intermediation helps build artificial trust and reputation, which may drive initial consumption. Consumer loyalty is still dependent on the outcome of peer-to-peer relations. 


\subsubsection{Impacts}

Benefits: Sharing platform systems and algorithms are capable of enhancing interactions between users and platforms, contributing to the development and environment of industries (Gargiulo et al., 2015; Ambrosino et al., 2016). The benefits of transport sharing platforms are service flexibility and service mobility, which in the long-run improve urban infrastructure and lead to sustainability (Furman, 2016; Gargiulo et al., 2015). For example, transport platforms are centred on the passengers' flexibility in optimising and customising services. This relates to the benefits of real-time interaction with suppliers, time and route optimisation, and the flexibility of payment methods. In particular, the application of the sharing economy systems in an urban environment can make it possible to increase the efficiency of public transport services, change daily customer journeys and overall urban mobility (Gargiulo et al., 2015). In the wider scope, the public shared transportation could tackle sustainability and environmental issues through the reduction of commercial and private car traffic, and the promotion of electric transport (Ambrosino et al., 2016). Similarly, apartment sharing would make it possible to optimise user interaction and energy consumption (Yeon-sun and ChangHee, 2016; Lombardi and Schwabe, 2017).

Challenges: The flexibility that platforms offer to providers can have positive and negative implications. On-demand employment gives drivers independence and the flexibility of workpatterns (Rosenblat and Stark, 2016). It may be convenient for those drivers seeking supplementary work, though it bears a regulatory challenge related to labour management (Rosenblat and Stark, 2016; Horney, 2016). The implication of the sharing economy for the labour market is defined by Rosenblat and Stark (2016) as algorithmic labour asymmetry. The positioning of alternative taxi companies as neutral technological intermediaries, providing flexible working opportunities for their drivers, contradicts the way drivers are actually treated. The shortcomings of algorithmic management are manifested in the neglect of drivers' rights in terms of wage rates. The platform sets a low salary rate for routine work and high incentives for work under stricter conditions. The salary policy forces drivers to adopt inflexible terms for the sake of making a better living (Rosenblat and Stark, 2016).

\section{Future Research Agenda}

The aim of the study was to tackle the limitations that have been observed in the exploratory research on the sharing economy so far. The main contribution of the paper is that it addresses the lack of comprehensive insight into this complex phenomenon by scrutinising its main underpinning concepts. It analysed the all-embracing building blocks of the sharing economy system in general rather than the collaborative consumption practices in specific industries. To do so the paper adopted a quantitative analysis, which made it possible to identify and classify the concepts discussed in the research. These concepts referred to resources, the practices of consumption, the areas of implication, user engagement factors and impacts. They were critically reviewed against the perspectives of the three types of stakeholders: suppliers, consumers and intermediaries. This analysis enabled us to analyse the differences in the practices of consumption, the motives for participation and impacts depending on the industry, the type of user and the technical specifications of platforms. 
The second contribution of the study originates from the objective to reflect on the multidimensional nature of the sharing economy, covering the patterns of economic transactions, social relations and technological characteristics. Despite the trend in the literature to represent the sharing economy either as an economic, social or technological phenomenon, the overarching publications did not analyse its dimensions. Hence, this paper contributes to the research by comparing and contrasting the concepts from the economic, social and technological perspectives. The findings in each stream of the literature are summarised in Figure 6. 
Figure 6: The development of themes and concepts in the economic, social and technological streams

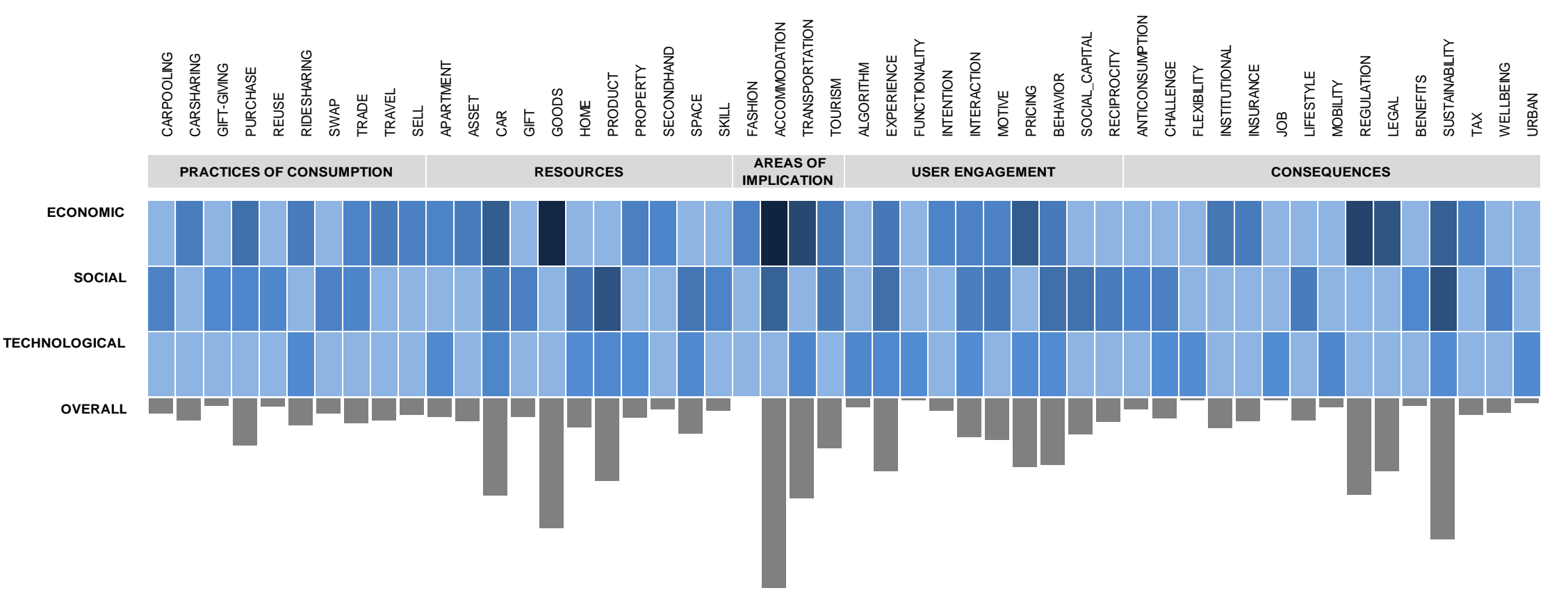

Weak

The degree of Themes and Concepts Development

Strong 
The findings demonstrate that well-researched topics are mainly underpinned by the economic perspective, while other areas remain relatively underdeveloped. The unequal development of research areas confines the "depth" and scope of research. Consequently, it leads to ambiguous findings about the acceptance and impact of the sharing economy. Given the gaps identified, future research could tackle the following overarching research questions (which are also discussed in more detail below):

1. What are the key values of consumption practices for users?

2. How do values affect the intention to participate in the sharing economy?

3. What are the factors that moderate the effect of drivers on the intention to participate in the sharing economy?

4. What are the long-term and short-term impacts of the sharing economy?

Need to Examine the Effect of User Values on Sharing Economy Acceptance: Value is the main antecedent of the intention to participate in collaborative consumption. The current research has identified the fact that users wield divergent values that differ across platforms. The analysis suggests that studying the value of consumption practices requires a close look at the relationship of three compounds: platform characteristics, the user role and the practice of resource distribution.

1) The technological perspective suggests that the architecture of the platform defines values and resource implications (de Rivera et al., 2017). The attention to technology is important because algorithms and the functionality of platforms create conditions under which the value of collaborative practices may become exhibited or left dormant. Given that, there is a need to diversify the range of platforms, based on the industry, their usability and functionality, embedded trust and reputation systems, the community footprint and rules of conduct. New studies could offer an insight into different premises of collaboration and test relations between system characteristics and values.

2) Research has been more inclined towards the consumer perspective. The adherence to a particular perspective is likely to provide a fragmented picture of a complex phenomenon. Therefore, future studies could adopt a comparative design to examine the difference in value perception of collaborative consumption by demand-side and supply-side users.

3) Current research has mainly investigated the distribution of tangible resources and compensated practices of consumption. Future research could contrast the findings of existing studies by focusing on the consumption of intangible resources, the practices of gift-giving and second-hand resource reusing.

4) From the methodological point of view, to test the role of values in collaborative consumption, future research needs to employ a cross-sectional design and a random sample. This would make it possible to ensure the generalisation of findings.

Need to Test the Effect of Moderating factors: To gain a richer understanding of user motives, future research could consider the effect of contextual forces, such as: cultural background, socio-economic factors and the level of platform mediation. 
1) To a major degree, the acceptance of the sharing economy is a user-centric type of research. It should be based on a clear understanding that the variability of drivers is dependent on user perception of the value of collaborative consumption. It requires a consideration of user background. This recommendation stems from the finding of Gruszka (2017), who concluded that user attitudes towards the sharing economy may vary based on personality traits. Hellwig et al. (2015) examined user personality traits for developing the sharing practices taxonomy. Future research may take these findings into account and employ a cross-cultural design to develop a taxonomy of values and collaborative behaviour across cultures.

2) A cross-cultural perspective would complement the observations made by Tussyadiah and Pesonen (2016), which suggest that older and wealthier users are driven by prosocial values of engaging in the sharing economy. It can be assumed that this finding may not be consistent in cultures where norms are rooted in more conservative ideologies.

3) The level of the technological moderation of platform transactions is an important variable to control in future studies, because it has an influence on the intimacy of user relations (Ertz, Durif, and Arcand, 2016). There is also a dearth of research examining the moderating effect of the trust and reputation systems on risk perception. This gap calls for an investigation into the indirect influence of technology characteristics on intention to engage in collaborative consumption.

Need to Examine the Impacts of the Sharing Economy: Published papers have intensively discussed the implications of the sharing economy on macroeconomic levels. The debates demonstrated that there is still scepticism about the available forecasts. Moreover, the impact of the sharing economy is a complex construct, measured by the nature of the effect, the scale of the effect and the influence on the stakeholders involved. Research needs to examine the social impact on an individual level, as well as empirically support the long-term impact, which has been the subject of debate.

1) Studies so far have examined the bridging role of social capital, which leads to social inclusion and the expansion of social networks (Barness and Mattsson, 2016; Kim, Lee, Koo and Yang, 2017; Ferrari, 2017). The bonding role of social capital has not been empirically investigated. To address this gap, future research needs to draw on social exchange theory perspectives to quantitatively examine the interaction effect of social capital and social exclusion.

2) There is a strong need to examine environmental sustainability from a social perspective. Specifically, research needs to investigate the drivers of a sustainable lifestyle and the long-term effect of anti-consumption behaviour on sustainability. Future research may benefit from adopting a longitudinal approach to assess the actual impact of reuse and recycle platforms on resource preservation and the reduction of the production of new goods.

3) Significant attention has been paid to the governance of platforms and the potential impact of the introduction of regulatory regimes. This points to the need for future research to examine the viability of various governance programmes and regulatory responses. 


\section{References}

Aloni, E. (2016), "Pluralizing The Sharing Economy".

Ambrosino, G., Nelson, J. D., Boero, M. \& Pettinelli, I. (2016), "Enabling Intermodal Urban Transport Through Complementary Services: From Flexible Mobility Services To The Shared Use Mobility Agency". Research In Transportation Economics, 59, 179-184.

Aptekar, S. (2016), "Gifts Among Strangers: The Social Organization Of Freecycle Giving". Social Problems, 63, 266-283.

Bachnik, K. (2016), "Sustainable Consumption Through The Sharing Economy". Konsumpcja Zrównoważona Stymulowana Gospodarkq Wspólnego Użytkowania., 35-44.

Bálint, D. \& Trócsányi, A. (2016), “New Ways Of Mobility: The Birth Of Ridesharing. A Case Study From Hungary". Hungarian Geographical Bulletin 65 (4), 391.

Ballús-Armet, I., Shaheen, S., Clonts, K. \& Weinzimmer, D. (2014), "Peer-To-Peer Carsharing: Exploring Public Perception And Market Characteristics In The San Francisco Bay Area, California". Transportation Research Record: Journal Of The Transportation Research Board, 27-36.

Bardhi, F. \& Eckhardt, G. M. (2012), Access-Based Consumption: The Case Of Car Sharing. Journal Of Consumer Research, 39, 881-898.

Barnes, S. J., and Mattsson, J. (2016), "Building Tribal Communities In The Collaborative Economy: An Innovation Framework". Prometheus, 34, 95-113.

Becker-Leifhold, C. \& Iran, S. (2018), Collaborative Fashion Consumption-Drivers, Barriers And Future Pathways. Journal Of Fashion Marketing And Management: An International Journal, 22, 189208.

Begum, L., and Anjum, M. (2016), "Beyond The Creative Class, Mapping The Collaborative Economy Of Bangladeshi Creative Industries: Case Study Of Oitij-Jo. South Asian Popular Culture, 14, 137153.

Belarmino, A., Whalen, E., Koh, Y., and Bowen, J. T.. (2017), “Comparing Guests' Key Attributes Of Peer-To-Peer Accommodations And Hotels: Mixed-Methods Approach". Current Issues In Tourism, 1-7.

Belk, R. (2010), Sharing. Journal Of Consumer Research, 36, 715-734.

Belk, R. (2014), "You Are What You Can Access: Sharing And Collaborative Consumption Online". Journal Of Business Research, 67, 1595-1600.

Binninger, A.-S., Ourahmoune, N. \& Robert, I. (2015), "Collaborative Consumption And Sustainability: A Discursive Analysis Of Consumer Representations And Collaborative Website Narratives". Journal Of Applied Business Research, 31, 969.

Birdsall, M. (2014), "Carsharing In A Sharing Economy". Institute Of Transportation Engineers. Ite Journal, 84, 37-40.

Böcker, L. \& Meelen, T. (2017), "Sharing For People, Planet Or Profit? Analysing Motivations For Intended Sharing Economy Participation". Environmental Innovation And Societal Transitions.

Bonciu, F. \& Bâlgar, A.-C. (2016), "Sharing Economy As A Contributor To Sustainable Growth. An Eu Perspective". Romanian Journal Of European Affairs, 16, 36-45.

Boons, F. \& Bocken, N. (2018), Towards A Sharing Economy-Innovating Ecologies Of Business Models. Technological Forecasting And Social Change, 137, 40-52.

Botsman, R. \& Rogers, R. (2011), What's Mine Is Yours: How Collaborative Consumption Is Changing The Way We Live, Collins London.

Bouncken, R. B. \& Reuschl, A. J. (2016), "Coworking-Spaces: How A Phenomenon Of The Sharing Economy Builds A Novel Trend For The Workplace And For Entrepreneurship". Review Of Managerial Science, 1-18. 
Bridges, J. \& Vásquez, C. (2016), If Nearly All Airbnb Reviews Are Positive, Does That Make Them Meaningless? Current Issues In Tourism, 1-19.

Cheng, M. \& Edwards, D. (2017), "A Comparative Automated Content Analysis Approach On The Review Of The Sharing Economy Discourse In Tourism And Hospitality". Current Issues In Tourism, 1-15.

Cheng, M. (2016), "Sharing Economy: A Review And Agenda For Future Research". International Journal Of Hospitality Management, 57, 60-70.

Cockayne, D. G. (2016), "Sharing And Neoliberal Discourse: The Economic Function Of Sharing In The Digital On-Demand Economy". Geoforum, 77, 73-82.

Cohen, B. \& Kietzmann, J. (2014), "Ride On! Mobility Business Models For The Sharing Economy". Organization \& Environment, 27, 279-296.

Cusumano, M. A. (2015), "How Traditional Firms Must Compete In The Sharing Economy". Communications of The Acm, 58, 32-34.

Dabrowska, A. \& Gutkowska, K. (2015), "Collaborative Consumption As A New Trend Of Sustainable Consumption". Acta Scientiarum Polonorum. Oeconomia, 14.

Davi, A., Haughton, D., Nasr, N., Shah, G., Skaletsky, M. \& Spack, R. (2005), "A Review Of Two TextMining Packages: Sas Textmining And Wordstat". The American Statistician, 59, 89-103.

De Leeuw, T. \& Gössling, T. (2016), "Theorizing Change Revisited: An Amended Process Model Of Institutional Innovations And Changes In Institutional Fields". Journal Of Cleaner Production, 135, 435-448.

De Rivera, J., Gordo, Á., Cassidy, P. \& Apesteguía, A. (2017), “A Netnographic Study Of P2p Collaborative Consumption Platforms' User Interface And Design". Environmental Innovation And Societal Transitions, 23, 11-27.

Dickinson, J. E., Hibbert, J. F., Filimonau, V., Cherrett, T., Davies, N., Norgate, S., Speed, C. \& Winstanley, C. (2017), "Implementing Smartphone Enabled Collaborative Travel: Routes To Success In The Tourism Domain". Journal Of Transport Geography, 59, 100-110.

Dredge, D. \& Gyimóthy, S. (2015), "The Collaborative Economy And Tourism: Critical Perspectives, Questionable Claims And Silenced Voices". Tourism Recreation Research, 40, 286-302.

Duran-Sanchez, A., Alvarez-Garcia, J., De La Cruz Del Rio-Rama, M. \& Patricia Maldonado-Erazo, C. (2016), "Collaborative Economy: Analysis Of Scientific Production In Academic Magazines". Revista De Gestao E Secretariado-Gesec, 7, 1-20.

Ellen, I.G.. (2015), "Housing Low-Income Households: Lessons From The Sharing Economy?" Housing Policy Debate, 25, 783-784.

Ertz, M., Durif, F. \& Arcand, M. (2016), "Collaborative Consumption: Conceptual Snapshot At A Buzzword". Journal Of Entrepreneurship Education, 19, 1-23.

Esben Rahbek Gjerdrum, P. \& Sarah, N. (2015), "Collaborative Consumption: Business Model Opportunities And Barriers For Fashion Libraries". Journal Of Fashion Marketing And Management: An International Journal, 19, 258-273.

Fagerstrøm, A., Pawar, S., Sigurdsson, V., Foxall, G. R. \& Yani-De-Soriano, M. (2017), "That Personal Profile Image Might Jeopardize Your Rental Opportunity! On The Relative Impact Of The Seller's Facial Expressions Upon Buying Behavior On Airbnb". Computers In Human Behavior, 72, 123-131.

Ferrari, M. Z. (2017), "Beyond Uncertainties In The Sharing Economy: Opportunities For Social Capital". European Journal Of Risk Regulation, 7, 664-674.

Forno, F., and Garibaldi, R. (2015), "Sharing Economy In Travel And Tourism: The Case Of HomeSwapping In Italy". Journal Of Quality Assurance In Hospitality \& Tourism, 16, 202-220.

Fremstad, A. (2017), "Does Craigslist Reduce Waste? Evidence From California And Florida". Ecological Economics, 132, 135-143. 
Frenken, K. \& Schor, J. (2017), "Putting The Sharing Economy Into Perspective". Environmental Innovation And Societal Transitions.

Furman, A. (2016), "Exploring Affordances Of The Street". Urban Regeneration \& Sustainability, 250.

Ganapati, S. \& Reddick, C. G. (2018), Prospects And Challenges Of Sharing Economy For The Public Sector. Government Information Quarterly.

Gargiulo, E., Giannantonio, R., Guercio, E., Borean, C. \& Zenezini, G. (2015). “Dynamic Ride Sharing Service: Are Users Ready To Adopt It?" Procedia Manufacturing, 3, 777-784.

Geigerr, A., Horbel, C., and Germelmann, C.C. (2017), "“Give And Take": How Notions Of Sharing And Context Determine Free Peer-To-Peer Accommodation Decisions". Journal Of Travel \& Tourism Marketing, 1-11.

Germann Molz, J. (2013), "Social Networking Technologies And The Moral Economy Of Alternative Tourism: The Case Of Couchsurfing.Org". Annals Of Tourism Research, 43, 210-230.

Gretzel, U., Werthner, H., Koo, C. \& Lamsfus, C. (2015), "Conceptual Foundations For Understanding Smart Tourism Ecosystems". Computers In Human Behavior, 50, 558-563.

Gruszka, K. (2017), "Framing The Collaborative Economy -Voices Of Contestation". Environmental Innovation And Societal Transitions, 23, 92-104.

Gullstrand Edbring, E., Lehner, M. \& Mont, O. (2016), "Exploring Consumer Attitudes To Alternative Models Of Consumption: Motivations And Barriers". Journal Of Cleaner Production, 123, 5-15.

Hamari, J. (2013). "Transforming Homo Economicus Into Homo Ludens: A Field Experiment On Gamification In A Utilitarian Peer-To-Peer Trading Service". Electronic Commerce Research And Applications, 12, 236-245.

Hamari, J., Sjöklint, M. \& Ukkonen, A. (2015), "The Sharing Economy: Why People Participate In Collaborative Consumption". Journal of The Association For Information Science And Technology.

Hartl, B., Hofmann, E. \& Kirchler, E. (2016), "Do We Need Rules For "What's Mine Is Yours"? Governance In Collaborative Consumption Communities". Journal Of Business Research, 69, 2756-2763.

Harvey, J., Smith, A. \& Golightly, D. (2014), "Giving And Sharing In The Computer-Mediated Economy". Journal Of Consumer Behaviour, N/A-N/A.

Hawlitschek, F., Teubner, T. \& Gimpel, H. (2016), “Understanding The Sharing Economy--Drivers And Impediments For Participation In Peer-To-Peer Rental. System Sciences (Hicss), 2016, 49th Hawaii International Conference On, 2016. leee, 4782-4791.

Hawlitschek, F., Teubner, T. \& Gimpel, H. (2018), Consumer Motives For Peer-To-Peer Sharing. Journal Of Cleaner Production, 204, 144-157.

Hellwig, K., Morhart, F., Girardin, F. \& Hauser, M. (2015), "Exploring Different Types Of Sharing: A Proposed Segmentation Of The Market For "Sharing" Businesses". Psychology \& Marketing, 32, 891-906.

Hendry, D. G., Woelfer, J. P. \& Duong, T. (2017), U-District Job Co-Op: Constructing A Future Vision For Homeless Young People And Employment. Information Technology \& People, 30, 602-628.

Heo, C. Y. (2016), "Sharing Economy And Prospects In Tourism Research". Annals Of Tourism Research, $58,166-170$.

Herbert, M. \& Collin-Lachaud, I. (2016), "Collaborative Practices And Consumerist Habitus: An Analysis Of The Transformative Mechanisms Of Collaborative Consumption". Recherche Et Applications En Marketing (English Edition), 32, 40-60.

Heylighen, F. (2017), "Towards An Intelligent Network For Matching Offer And Demand: From The Sharing Economy To The Global Brain". Technological Forecasting And Social Change, 114, 7485.

Hobson, K. \& Lynch, N. (2016), "Diversifying And De-Growing The Circular Economy: Radical Social Transformation In A Resource-Scarce World". Futures, 82, 15-25. 
Hong, J., Shin, J. \& Lee, D. (2016), "Strategic Management Of Next-Generation Connected Life: Focusing On Smart Key And Car-Home Connectivity". Technological Forecasting And Social Change, 103, 11-20.

Hong, S. \& Vicdan, H. (2016), "Re-Imagining The Utopian: Transformation Of A Sustainable Lifestyle In Ecovillages". Journal Of Business Research, 69, 120-136.

Horney, N. (2016), "The Gig Economy: A Disruptor Requiring Hr Agility". People \& Strategy, 39, $20-27$.

Hsieh, H.-F. \& Shannon, S. E. (2005), "Three Approaches To Qualitative Content Analysis". Qualitative Health Research, 15, 1277-1288.

Huber, A. (2017), "Theorising The Dynamics Of Collaborative Consumption Practices: A Comparison Of Peer-To-Peer Accommodation And Cohousing". Environmental Innovation And Societal Transitions, 23, 53-69.

Humphreys, A. \& Wang, R. J.-H. 2017. Automated Text Analysis For Consumer Research. Journal Of Consumer Research, 44, 1274-1306.

Jiyoung, H. \& Merlyn, A. G. (2017), "Share More, Drive Less: Millennials Value Perception And Behavioral Intent In Using Collaborative Consumption Services". Journal Of Consumer Marketing, 34, 132-146.

Karlsson, L., Kemperman, A. \& Dolnicar, S. (2017), "May I Sleep In Your Bed? Getting Permission To Book". Annals Of Tourism Research, 62, 1-12.

Kathan, W., Matzler, K. \& Veider, V. (2016), "The Sharing Economy: Your Business Model's Friend Or Foe?" Business Horizons, 59, 663-672.

Kennedy, J. (2016), "Conceptual Boundaries Of Sharing". Information, Communication \& Society, 19, 461-474.

Kim, J., Yoon, Y. \& Zo, H. (2015), "Why People Participate In The Sharing Economy: A Social Exchange Perspective". Pacis, 76.

Kim, S. \& Yoon, Y. (2016), "Recommendation System For Sharing Economy Based On Multidimensional Trust Model”. Multimedia Tools And Applications, 75, 15297-15310.

Knote, R. \& Blohm, I. (2016), "Deconstructing The Sharing Economy: On The Relevance For Is Research". Multikonferenz Wirtschaftsinformatik, Mkwi 2016, 45-54.

Kotsiantis, S. B., Zaharakis, I. \& Pintelas, P. (2007), "Supervised Machine Learning: A Review Of Classification Techniques".

Kung, L.-C. \& Zhong, G.-Y. (2017), "The Optimal Pricing Strategy For Two-Sided Platform Delivery In The Sharing Economy". Transportation Research Part E: Logistics And Transportation Review, 101, 1-12.

Laamanen, M., Wahlen, S. \& Campana, M. (2015), "Mobilising Collaborative Consumption Lifestyles: A Comparative Frame Analysis Of Time Banking". International Journal Of Consumer Studies, 39, 459-467.

Lamberton, C. (2016), "Collaborative Consumption: A Goal-Based Framework". Current Opinion In Psychology, 10, 55-59.

Lampinen, A., Huotari, K. \& Cheshire, C. (2015), “Challenges To Participation In The Sharing Economy: The Case Of Local Online Peer-To-Peer Exchange In A Single Parents' Network". Ixd\&A, 24, 1632.

Laurell, C. \& Sandström, C. (2016), “Analysing Uber In Social Media-Disruptive Technology Or Institutional Disruption?" International Journal Of Innovation Management, 20, 1640013.

Lee, Seunghwan, and Dae-Young Kim. (2017), "Brand Personality Of Airbnb: Application Of User Involvement And Gender Differences". Journal Of Travel \& Tourism Marketing, 1-14.

Lessig, L. (2008), Remix: Making Art And Commerce Thrive In The Hybrid Economy, Penguin.

Lombardi, P. \& Schwabe, F. (2017), "Sharing Economy As A New Business Model For Energy Storage Systems!. Applied Energy, 188, 485-496. 
Malin, B. J. \& Chandler, C. (2017), "Free To Work Anxiously: Splintering Precarity Among Drivers For Uber And Lyft". Communication, Culture \& Critique, 10, 382-400.

Martin, C. J., Upham, P. \& Budd, L. (2015), "Commercial Orientation In Grassroots Social Innovation: Insights From The Sharing Economy". Ecological Economics, 118, 240-251.

Matteo, C. \& Daniele, D. (2014), "Gift-Giving, Sharing And Commodity Exchange At Bookcrossing.Com: New Insights From A Qualitative Analysis". Management Decision, 52, 755-776.

McArthur, E. (2015), "Many-To-Many Exchange Without Money: Why People Share Their Resources". Consumption Markets \& Culture, 18, 239-256.

Miller, S. R. (2016), First Principles For Regulating The Sharing Economy. Browser Download This Paper.

Morgan, B. \& Kuch, D. (2015), Radical Transactionalism: Legal Consciousness, Diverse Economies, And The Sharing Economy. Journal Of Law And Society, 42, 556-587.

Morgan, B. (2018), The Sharing Economy. Annual Review Of Law And Social Science.

Munkøe, M. M. (2017), Regulating The European Sharing Economy: State Of Play And Challenges. Intereconomics, 52, 38-44.

Nahapiet, J. \& Ghoshal, S. (1998), "Social Capital, Intellectual Capital, And The Organizational Advantage". Academy of Management Review, 23, 242-266.

Ndubisi, N. O., Ehret, M. \& Wirtz, J. (2016), "Relational Governance Mechanisms And Uncertainties In Nonownership Services". Psychology \& Marketing, 33, 250-266.

Oskam, J. \& Boswijk, A. (2016), "Airbnb: The Future Of Networked Hospitality Businesses". Journal Of Tourism Futures, 2, 22-42.

Pfeffer-Gillett, A. (2016), "When Disruption Collides With Accountability: Holding Ridesharing Companies Liable For Acts Of Their Drivers". Cal. L. Rev., 104, 233.

Piscicelli, L., Cooper, T. \& Fisher, T. (2015), "The Role Of Values In Collaborative Consumption: Insights From A Product-Service System For Lending And Borrowing In The Uk". Journal Of Cleaner Production, 97, 21-29.

Posen, H. A. (2015), "Ridesharing In The Sharing Economy: Should Regulators Impose Uber Regulations On Uber". lowa L. Rev., 101, 405.

Redfearn lii, R. L. (2016), "Sharing Economy Misclassification: Employees And Independent Contractors In Transportation Network Companies". Berkeley Technology Law Journal, 31, 1023-1056.

Retamal, M. (2017), "Product-Service Systems In Southeast Asia: Business Practices And Factors Influencing Environmental Sustainability". Journal Of Cleaner Production, 143, 894-903.

Richardson, L. (2015), "Performing The Sharing Economy". Geoforum, 67, 121-129.

Riff, D., Lacy, S. \& Fico, F. (2013), Analyzing Media Messages, Routledge.

Rosenblat, A. \& Stark, L. (2016), "Algorithmic Labor And Information Asymmetries: A Case Study Of Uber's Drivers".

Rózycka, M. (2016), "Collaborative Consumption - A New Trend In The Economy". World Scientific News, 48, 188-192.

Sahlins, M.D. (1974), "Stone age economics". Vol. 130. Transaction Publishers.

Santos, G. (2018), Sustainability And Shared Mobility Models. Sustainability, 10, 3194.

Scaraboto, D. (2015), "Selling, Sharing, And Everything In Between: The Hybrid Economies Of Collaborative Networks". Journal Of Consumer Research, 42, 152-176.

Schor, J. B., Fitzmaurice, C., Carfagna, L. B., Attwood-Charles, W. \& Poteat, E. D. (2016), "Paradoxes Of Openness And Distinction In The Sharing Economy". Poetics, 54, 66-81.

Shaheen, S. \& Chan, N. (2016), "Mobility And The Sharing Economy: Potential To Facilitate The FirstAnd Last-Mile Public Transit Connections". Built Environment, 42, 573-588.

Shaheen, S. A., Chan, N. D. \& Gaynor, T. (2016), "Casual Carpooling In The San Francisco Bay Area: Understanding User Characteristics, Behaviors, And Motivations". Transport Policy, 51, 165173.

Silver, C. (2014), Qda Miner (With Wordstat And Simstat). Journal Of Mixed Methods Research. 
Sinclair, M. (2016), "Fair And Efficient Regulation Of The Sharing Economy". Economic Affairs, 36, 204211.

Sprague, R. (2015), "Worker (Mis)Classification In The Sharing Economy: Trying To Fit Square Pegs Into Round Holes". Aba Journal Of Labor \& Employment Law, 31, 53-76.

Sutherland, W. \& Jarrahi, M. H. (2018), The Sharing Economy And Digital Platforms: A Review And Research Agenda. International Journal Of Information Management, 43, 328-341.

Tan, P.-N. (2006), Introduction To Data Mining, Pearson Education India.

Tham, A. (2016), "When Harry Met Sally: Different Approaches Towards Uber And Airbnb-An Australian And Singapore Perspective". Information Technology \& Tourism, 16, 393-412.

Tranfield, D., Denyer, D. \& Smart, P. (2003), "Towards A Methodology For Developing EvidenceInformed Management Knowledge By Means Of Systematic Review". British Journal Of Management, 14, 207-222.

Trenz, M., Frey, A. \& Veit, D. (2018), Disentangling The Facets Of Sharing: A Categorization Of What We Know And Don't Know About The Sharing Economy. Internet Research, 00-00.

Tussyadiah, I. P. \& Pesonen, J. (2015), "Impacts Of Peer-To-Peer Accommodation Use On Travel Patterns". Journal Of Travel Research, 55, 1022-1040.

Tussyadiah, I. P. (2015), "An Exploratory Study On Drivers And Deterrents Of Collaborative Consumption In Travel". Information And Communication Technologies In Tourism (2015). Springer.

Tussyadiah, lis P, and Juho Pesonen. (2016), "Drivers And Barriers Of Peer-To-Peer Accommodation Stay - An Exploratory Study With American And Finnish Travellers". Current Issues In Tourism, 1-18.

Van Nuenen, T. (2016), "The Production Of Locality On Peer-To-Peer Platforms". Cogent Social Sciences, 2

Voytenko Palgan, Y., Zvolska, L. \& Mont, O. (2017), "Sustainability Framings Of Accommodation Sharing". Environmental Innovation And Societal Transitions, 23, 70-83.

Waite, L. \& Lewis, H. (2017), "Precarious Irregular Migrants And Their Sharing Economies: A Spectrum Of Transactional Laboring Experiences". Annals Of The American Association Of Geographers, 1-15.

Wang, D. \& Nicolau, J. L. (2017), "Price Determinants Of Sharing Economy Based Accommodation Rental: A Study Of Listings From 33 Cities On Airbnb.Com". International Journal Of Hospitality Management, 62, 120-131.

Watanabe, C., Naveed, K., Neittaanmäki, P. \& Fox, B. (2017), "Consolidated Challenge To Social Demand For Resilient Platforms - Lessons From Uber's Global Expansion". Technology In Society, 48, 33-53.

Weber, T.A. (2014), "Intermediation In A Sharing Economy: Insurance, Moral Hazard, And Rent Extraction". Journal Of Management Information Systems, 31, 35-71.

Whitham, M. M. \& Clarke, H. (2016), "Getting Is Giving: Time Banking As Formalized Generalized Exchange". Sociology Compass, 10, 87-97.

Wyatt, A. (2014), "My House Is Your House". Planning, 80, 41-43.

Yang, S., Song, Y., Chen, S. \& Xia, X. (2017), "Why Are Customers Loyal In Sharing-Economy Services? A Relational Benefits Perspective". Journal Of Services Marketing, 31.

Yeon-Sun, H. \& Chang-Hee, K. (2016), "A Study On The Sharing Economy Apartments And It's Ubiquitous Monitoring System". International Journal Of Smart Home, 10, 249-258.

Yuan, C. W., Hanrahan, B. V. \& Carroll, J. M. (2018), Assessing Timebanking Use And Coordination: Implications For Service Exchange Tools. Information Technology \& People.

Zhang, L., Yan, Q. \& Zhang, L. (2018), A Computational Framework For Understanding Antecedents Of Guests' Perceived Trust Towards Hosts On Airbnb. Decision Support Systems, 115, 105-116. 